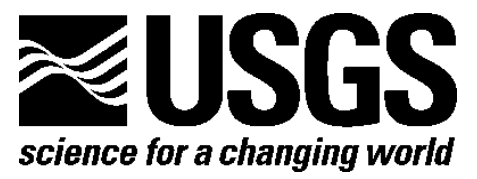

\title{
Distribution and Extent of Heavy Metal Accumulation in Song Sparrows (Melospiza melodia), Upper Santa Cruz River Watershed, Southern Arizona, 2011-12
}

By Michael B. Lester and Charles van Riper III

Open-File Report 2014-1072

U.S. Department of the Interior

U.S. Geological Survey 


\section{U.S. Department of the Interior \\ SALLY JEWELL, Secretary}

\section{U.S. Geological Survey \\ Suzette M. Kimball, Acting Director}

U.S. Geological Survey, Reston, Virginia: 2014

For more information on the USGS-the Federal source for science about the Earth, its natural and living resources, natural hazards, and the environment-visit

http://www.usgs.gov or call 1-888-ASK-USGS

For an overview of USGS information products, including maps, imagery, and publications, visit $h$ ttp://www.usgs.gov/pubprod

To order this and other USGS information products, visit http://store.usgs.gov

Suggested citation:

Lester, M.B., and van Riper, III, Charles, 2014, Distribution and extent of heavy metal accumulation in Song Sparrows (Melospiza melodia), upper Santa Cruz River watershed, southern Arizona, 2011-12: U.S. Geological Survey Open-File Report 2014-1072 32 p., http://dx.doi.org/10.3133/ofr20141072.

ISSN 2331-1258 (online)

Any use of trade, product, or firm names is for descriptive purposes only and does not imply endorsement by the U.S. Government.

Although this report is in the public domain, permission must be secured from the individual copyright owners to reproduce any copyrighted material contained within this report. 


\section{Contents}

Abstract

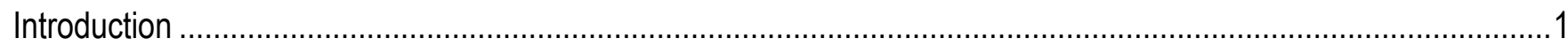

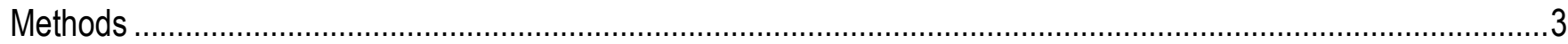

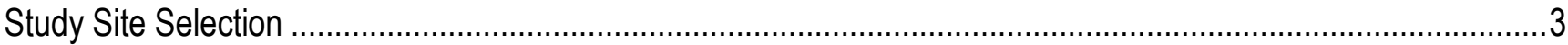

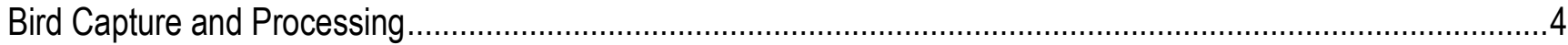

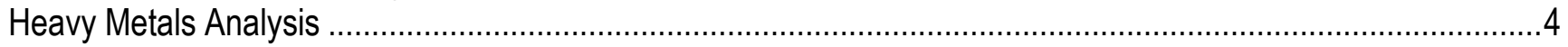

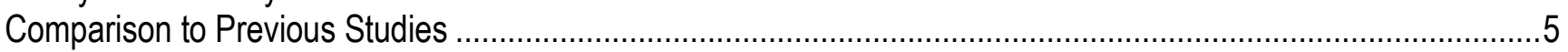

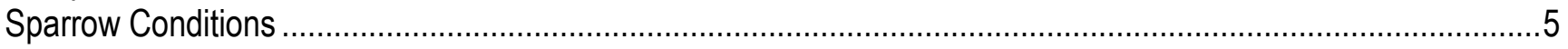

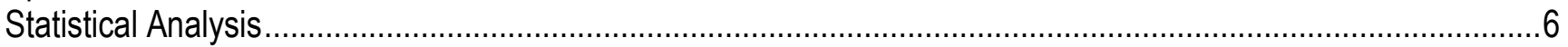

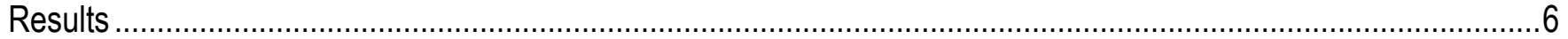

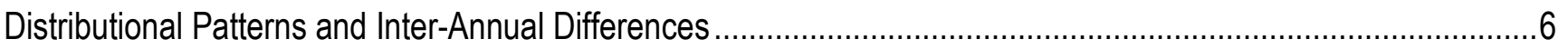

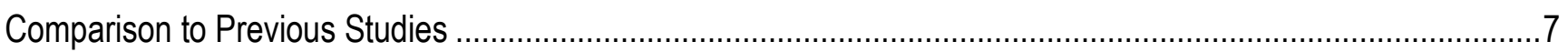

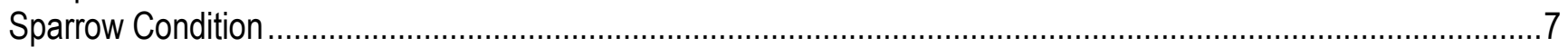

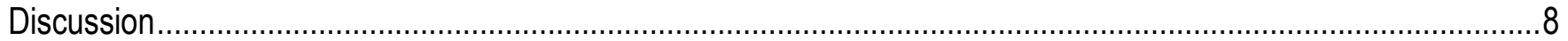

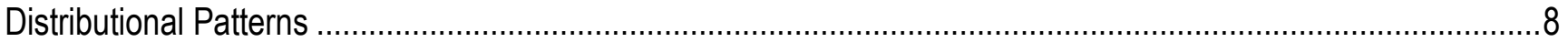

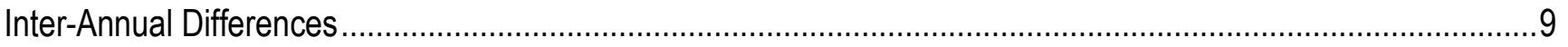

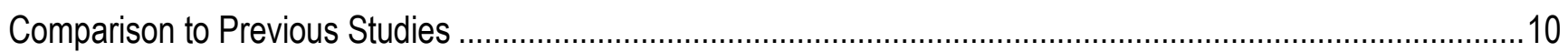

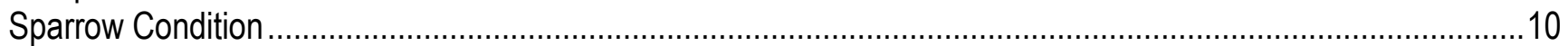

Heavy Metals Exceeding Average Background Concentrations ...................................................................12

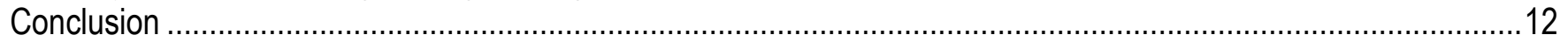

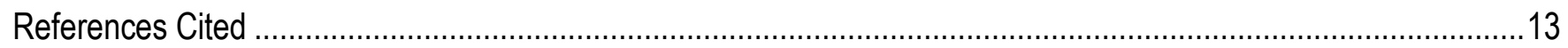

\section{Figures}

Figure 1. A Song Sparrow (Melospiza melodia) shortly after being captured downstream of the outfall at the Nogales International Wastewater Treatment Plant, southern Arizona ............................................................18

Figure 2. Schematic showing locations (latitude 313833; longitude 1109158) of six study sites in the upper Santa Cruz River watershed, southern Arizona, 2011-12

Figure 3. Study site at the headwaters of the Santa Cruz River (latitude 313833; longitude 1106275) east of Lochiel, southern Arizona, in the San Rafael Grasslands .........................................................................19

Figure 4. A Javelina (Pecari tajacu) crossing our study site at Nogales Wash, southern Arizona ............................19

Figure 5. A cow drinks water from one of our study sites along Sonoita Creek (latitude 313500; longitude 1108437), near Patagonia Lake, southern Arizona.

Figure 6. Our study site at the outfall of the Nogales International Wastewater Treatment

Plant in southern Arizona ....

Figure 7. Santa Cruz River at Tumacacori National Historical Park (latitude 315500; longitude 1100600, southern Arizona

Figure 8. A field technician sets up a mist net across Sonoita Creek, below Patagonia Lake, southern Arizona, to help capture Song Sparrows (Melospiza melodia)

Figure 9. A field technician draw blood from a Song Sparrow (Melospiza melodia) at our control site, Lochiel (LOCH), southern Arizona. 
Figure 10. Comparison of the heavy metals from birds in the1997 U.S. Fish and Wildlife Service study at Rio Rico North site (King and others, 1999) with the present study at sites Nogales International Waste Water Treatment Plant (NIWWTP) and Tumacacori National Historical Park (TUMA), in southern Arizona

Figure 11. Comparison of heavy metals in Abert's Towhees (Melozone aberti) and Yellow-breasted Chats (Icteria virens) from the Kirkpatrick and others (2010) study with Song Sparrows (Melospiza melodia) in the present study.

Figure 12. Mean hematocrit (percent red blood cells) of adult male and female Song Sparrows (Melospiza melodia) captured within the upper Santa Cruz River watershed, Arizona, during 2011 and 2012........24 Figure 13. Mean proportion of white blood cells per total number of cells read for Song Sparrows (Melospiza melodia) in 2011 and 2012 at six field sites within the upper Santa Cruz River watershed, southern Arizona..........25 Figure 14. Mean body mass residual score of adult Song Sparrows (Melospiza melodia) in 2011 and 2012 for six sites within the upper Santa Cruz River watershed, southern Arizona

\section{Tables}

Table 1. Mean natural $\log (\mathrm{Ln})$ in parts per million and standard error (SE) of 21 heavy metals in tail feathers of adult Song Sparrows at six sites in the upper Santa Cruz River watershed, southern Arizona, 2011

Table 2. Mean natural $\log (\mathrm{Ln})$ in parts per million and standard error (SE) of 21 heavy metals in tail feathers of adult Song Sparrows at six sites in the upper Santa Cruz River watershed, southern Arizona, 2012.

Table 3. Mean difference in natural log-transformed (Ln) heavy metal concentrations between 2011 and 2012 for feathers of 37 Song Sparrows (Melospiza melodia) captured during both years of our study in the upper Santa Cruz River watershed, southern Arizona

Table 4. Mean difference in natural log-transformed (Ln) heavy metal concentrations between 2011 and 2012 for feathers of all adult Song Sparrows (Melospiza melodia) captured in the upper Santa Cruz River watershed, southern Arizona.

Table 5. Mean natural log (Ln) in parts per million and standard error of 21 elements in blood of adult Song Sparrows at six sites in the upper Santa Cruz River watershed, Arizona, 2011

Table 6. Mean Ln (PPM) and standard error of 21 elements found in blood of adult Song Sparrows at six sites within the upper Santa Cruz River watershed, Arizona, 2012

Table 7. Mean difference in log-transformed (Ln) heavy metal concentrations between 2011 and 2012 for blood samples of 33 Song Sparrows (Melospiza melodia) that were captured in both years of our study in the upper Santa Cruz River watershed, southern Arizona

Table 8. Mean difference in log-transformed (Ln) heavy metal concentrations between 2011 and 2012 for blood samples of all adult Song Sparrows (Melospiza melodia) captured in the upper Santa Cruz River 


\section{Conversion Factors}

Inch/Pound to SI

\begin{tabular}{lll}
\hline \multicolumn{1}{c}{ Multiply } & \multicolumn{1}{c}{ By } & \multicolumn{1}{c}{ To obtain } \\
\hline mile (mi) & Length & \\
\hline \multicolumn{1}{c}{ Multiply } & 1.609 & kilometer (km) \\
\hline \multicolumn{1}{c}{ BI to Inch/Pound } & \multicolumn{1}{c}{ To obtain } \\
\hline \multicolumn{1}{c}{ By } & \\
\hline centimeter (cm) & Length & inch (in.) \\
millimeter (mm) & 0.393 & inch (in.) \\
meter (m) & 0.039 & foot (ft) \\
kilometer (km) & 3.280 & mile (mi) \\
meter (m) & 0.621 & yard (yd) \\
\hline
\end{tabular}

Temperature in degrees Celsius $\left({ }^{\circ} \mathrm{C}\right)$ may be converted to degrees Fahrenheit $\left({ }^{\circ} \mathrm{F}\right)$ as follows:

$$
{ }^{\circ} \mathrm{F}=\left(1.8 x^{\circ} \mathrm{C}\right)+32 .
$$


This page left intentionally blank 


\title{
Distribution and Extent of Heavy Metal Accumulation in Song Sparrows (Melospiza melodia), Upper Santa Cruz River Watershed, Southern Arizona, 2011-12
}

\author{
By Michael B. Lester and Charles van Riper III
}

\begin{abstract}
Riparian ecosystems in arid environments provide critical habitat for breeding, migratory, and wintering birds, yet are often at risk of contamination by heavy metals. Birds and other animals living in contaminated areas are susceptible to adverse health effects as a result of long-term exposure and bioaccumulation of heavy metals. We investigated the distribution and cascading extent of heavy metal accumulation in Song Sparrows (Melospiza melodia) in Arizona's upper Santa Cruz River watershed. This study had three goals: (1) quantify the degree of heavy metal accumulation in sparrows and determine the distributional patterns among study sites, (2) compare concentrations of metals found in this study to those found in studies performed prior to the 2009 international wastewater treatment plant upgrade, and (3) assess sparrow condition among sites with differing potential sources of contamination exposure.

We examined six study sites that reflected different potential sources of contamination. Hematocrit values, body mass residuals, and leukocyte counts were used to assess sparrow condition. Cadmium, copper, mercury, nickel, and selenium exceeded background concentrations at some sites, but generally were lower than or similar to concentrations found in earlier studies performed prior to the 2009 international wastewater treatment plant upgrade. Concentrations were higher in recaptured birds in 2012 than in 2011 for 7 metals in feathers and 14 metals in blood, suggesting possible bioaccumulation. We found no cascading effects as a result of heavy metal exposure, but did find that heavy metal concentrations were reduced following the 2009 international wastewater treatment plant upgrade.
\end{abstract}

\section{Introduction}

Riparian woodlands provide a critical resource for breeding, migratory, and wintering birds, and support more species than any other vegetation type in southern Arizona (Johnson and others, 1977; Knopf and others, 1988; Rich and others, 2004). However, this vegetation type is often at risk of degradation due to anthropogenic activities (Webb and Leake, 2006). The degradation of riparian systems can have detrimental impacts on the avian community and other organisms living within the ecosystem, including humans. Therefore, understanding how birds respond to living in a polluted environment is crucial for making management decisions regarding southwestern riparian communities. 
The upper Santa Cruz River in southern Arizona is dry throughout most of the year, but a $35 \mathrm{~km}$ stretch was revived in the mid-1900s when the river was filled with treated effluent from the Nogales International Wastewater Treatment Plant (Sonoran Institute, 2007), which treats water from Nogales, Arizona, and Nogales, Sonora. Furthermore, the river receives water from intermittent tributaries that flow through abandoned mining or urban areas. The upper reaches of the river now support lush riparian vegetation, but concerns about water quality have arisen because heavy metals, pesticides, and other contaminants have been discovered in the river (King and others, 1999; Kirkpatrick and others, 2009). Water quality also may be affecting local fauna. Avian monitoring at Tumacacori National Historical Park, approximately $17 \mathrm{~km}$ downstream of the Nogales wastewater treatment plant, found a relatively high incidence of deformities between 2001 and 2009 (Turner, 2001; Kirkpatrick and others, 2010), possibly indicative of high contaminant levels (Craves, 1994). Moreover, cattle regularly feed and drink along the upper Santa Cruz River and also may be at risk of bioaccumulation, as are the humans that consume the beef, thus highlighting the need for monitoring.

In 1997, the U.S. Fish and Wildlife Service (USFWS) carried out an intensive study to assess the extent of contamination in water, sediment, fish, invertebrate, and bird populations within the upper Santa Cruz River watershed (King and others, 1999). In particular, Killdeer (Charadrius vociferus) were collected and examined for concentrations of heavy metals and organochlorines. The study found that birds are within the non-toxic range for cadmium, lead, mercury, and selenium (King and others, 1999). However, the migratory habits of Killdeer make it a less-than-desirable subject for studying chronic contamination because (1) it is difficult to determine if birds accumulated contaminants on breeding, wintering, or migration stopover sites, and (2) non-residents do not spend as much of their life at these contaminated sites as do residents (King and others, 1999).

Song Sparrows (Melospiza melodia; fig. 1) provide an ideal subject for studying the extent of contaminant exposure because their non-migratory habits in the Southwest (Davis and Arcese, 1999) will mean that any contaminants they may have did not come from other locations, such as wintering grounds. Moreover, Song Sparrows in the Southwest rely heavily on riparian vegetation, feeding on aquatic insects and invertebrates, especially during the breeding season (Aldrich, 1985). As a result, individuals can be directly exposed to contaminants through foraging.

A study of the upper Santa Cruz River is important because contaminants, such as heavy metals, can have profound effects on the ecosystem. Therefore, an unhealthy avian community may be an indication of detrimental conditions for other wildlife and for humans living along the Santa Cruz River corridor. The effects of contaminants on avian immunity are of particular interest, as exposure to contaminants may increase vulnerability to diseases through suppression of the immune system (Grasman, 2002). For example, organisms that are higher on the food chain are especially susceptible to bioaccumulative effects (Winter and Streit, 1992). For instance, harbor seals fed contaminated fish in northwestern Europe showed reduced natural killer cell function (Van Loveren and others, 2000), whereas lead exposure in birds has correlated with the protozoan parasite Trichomonas gallinae in Mourning Doves (Zenaida macroura; Locke and Bagley, 1967), as well as the fungal disease aspergillosis and avian cholera in waterfowl (Rocke and Samuel, 1991). Body condition also is negatively correlated with disease condition and positively correlated with immune function (MØller and others, 1998). Reduced body condition may consequently lead to lower reproductive output (Chastel and others, 1995). 
This study was part of a collaborative effort to quantify the levels of contaminants in the upper Santa Cruz River ecosystem, including water, sediments, plants, insects, fish, and birds. Our assumption was that the distribution of metal concentrations in birds would represent the metal's sources, such that birds occupying study sites in urban and mining areas will have higher heavy metal burdens than birds downstream of the Nogales wastewater treatment plant, which, in turn, will have higher burdens than birds at our control site. The objectives of our study were to: (1) quantify the concentrations and distributional patterns of heavy metals in blood and feathers of Song Sparrows among the six study sites, (2) compare with prior studies to assess the extent of heavy metal accumulation in birds at downstream sites after the 2009 wastewater treatment plant upgrade, and (3) quantify hematocrit values, body conditions (that is, residual body mass), and immune conditions (as a measure of leukocyte count) for Song Sparrows captured at six field sites throughout the upper Santa Cruz River watershed. These objectives allowed us to determine if birds were accumulating heavy metals over time and in patterns consistent with their source, to examine how heavy metal concentrations have changed over time, and to investigate the condition and response of birds living in a contaminated environment. This study also was done to provide a baseline of information to which future studies can compare changes in heavy metal concentrations over time.

\section{Methods}

\section{Study Site Selection}

The Santa Cruz River flows southward from its headwaters in the San Rafael Grasslands of southeastern Arizona, United States, into Sonora, Mexico. It then skirts around the Sierra San Antonio mountain range, where it turns northward and re-enters the United States just east of Nogales, Arizona. Six sites within the upper Santa Cruz River watershed were selected for study, each with various degrees and sources of contamination (fig. 2).

- Site LOCH, our control site, was located along the headwaters of the Santa Cruz River in San Rafael State Natural Area, east of the town of Lochiel (fig. 3). This site was upstream of all other sites and was used as a baseline because the area is closed to the general public and experiences the least amount of human disturbance and potential contamination.

- Site NOWA was located at Nogales Wash, a tributary that leads directly into the Santa Cruz River (fig. 4). NOWA is located within urban cities of Nogales (Arizona and Mexico) and receives runoff from those cities.

- Sites PLSP and SOCR were located at Sonoita Creek, which is another tributary of the Santa Cruz River, and receives runoff from abandoned mining areas in the Patagonia Mountains (Norman and others, 2008; fig. 5). Sonoita Creek is dammed to create Patagonia Lake, a popular recreational state park, before continuing toward the Santa Cruz River. Because contaminants in the water may precipitate out or settle once reaching the lake, we established one study site upstream of the lake (PLSP) and another site downstream of the lake (SOCR).

- Site NIWWTP was located just downstream of the Nogales International Wastewater Treatment Plant, at the plant's outfall (fig. 6). This facility treats approximately 15-17 million gal of sewage per day from the cities of Nogales, Sonora, and Nogales, Arizona, and the treated effluent is released into the Santa Cruz River.

- Site TUMA was located along the Santa Cruz River at Tumacacori National Historical Park, which is approximately $17 \mathrm{~km}$ farther downstream of the Nogales International Wastewater Treatment Plant (fig. 7). 


\section{Bird Capture and Processing}

Song Sparrows were captured at all sites primarily between April 1 and June 30, 2011 and 2012, with birds also captured in July and August 2011 and 2012 at TUMA. We used 6- and 12-m mist nets (30-mm mesh) to target individual Song Sparrows (fig. 8).

At most sites, we captured birds using these nets either by broadcasting Song Sparrow calls and songs, or by flushing them into nets while they were foraging or sitting on a nest. In addition, banding at TUMA occurred in conjunction with a Monitoring Avian Productivity and Survivorship (MAPS) station. Therefore, at this site we used constant-effort mist-netting techniques rather than target netting to capture Song Sparrows. Birds were banded, aged (after hatch year versus hatch year), and sexed (male versus female). Tarsus-metatarsus length and mass were recorded (Ralph and others, 1993). Outer tail feathers (rectrices) and blood samples from the brachial vein also were collected (fig. 9).

\section{Heavy Metals Analysis}

Feathers and blood were used as biomarkers to demonstrate the extent of long-term and immediate exposure, respectively. Blood and feather samples collected from each bird were sent to Activation Laboratories Ltd. (Ontario, Canada) for preparation and heavy metal analysis. Samples were analyzed for 21 focal heavy metals primarily chosen based on previous studies (King and others, 1999; Kirkpatrick and others, 2010). These focal heavy metals included silver (Ag), aluminum (Al), arsenic $(\mathrm{As})^{1}$, barium $(\mathrm{Ba})$, cadmium $(\mathrm{Cd})$, chromium $(\mathrm{Cr})$, copper $(\mathrm{Cu})$, iron $(\mathrm{Fe})$, mercury $(\mathrm{Hg})$, magnesium (Mg), manganese (Mn), molybdenum (Mo), nickel (Ni), lead (Pb), antimony (Sb), selenium (Se) ${ }^{1}$, strontium (Sr), thallium (Tl), uranium (U), vanadium (V), and zinc (Zn). Background concentrations of heavy metals in blood and feathers were determined from previous studies that examined concentrations of heavy metals in birds at unpolluted reference sites (Llacuna and others, 1995; Burger and Gochfeld, 1997; Evers and others, 1998; Eens and others, 1999; Kahle and Becker, 1999; Thompson and Dowding, 1999; Dmowski, 2000; Janssens and others, 2001; Osofsky and others, 2001; van Wyk and others, 2001; Wayland and others, 2001; Dauwe and others, 2002; Golden and others, 2003; Martinez-Lopez and others, 2005; Morrissey and others, 2005; Nam and others, 2005; Deng and others, 2007; Matz and Rocque, 2007; Pan and others, 2008; Rattner and others, 2008; Costa and others, 2011; Abduljaleel and others, 2012; Lane and others, 2012).

Feathers.-Feathers are often used as a biomonitor of heavy metal contamination because they remain connected to the blood source until they have fully grown. As a result, metals in blood can become concentrated in feathers over a longer period of time than blood, making them easier to detect (Braune and Gaskin, 1987; Burger, 1993). In order to remove external contamination, feathers were twice washed with deionized water followed by $1 \mathrm{~mol} / \mathrm{L}$ acetone (Optima ${ }^{\mathrm{TM}}$ grade, Fisher Scientific; Burger and others, 1992). Samples were dried in a clean $45^{\circ} \mathrm{C}$ oven for $4-5$ hours and then weighed. In order to digest the samples, nitric acid (Optima ${ }^{\mathrm{TM}}$ grade, Fisher Scientific) and hydrogen peroxide (Ultra ${ }^{\mathrm{TM}}$ grade, Thermo Fisher Scientific) were alternately added to each sample, shaken, and twice heated at $85^{\circ} \mathrm{C}$ in a $\mathrm{JULABO}^{\odot}$ hot water bath. The ratio of nitric acid to hydrogen peroxide was approximately 3:1. All samples were then diluted to $5 \mathrm{~mL}$ with deionized water and spiked with internal standards for quality control. Concentrations of heavy metals were measured with a Finnigan ${ }^{\mathrm{TM}}$ Element-2 (Thermo Fisher Scientific) high performance high resolution inductively coupled plasmamass spectrometer (HR ICP-MS). The recoveries ranged from 85 to 110 percent.

\footnotetext{
${ }^{1}$ Although As and Se are not truly heavy metals, for simplicity they will be referred to as such throughout this report.
} 
Blood.-Unlike feathers, blood is constantly circulating and being filtered by organs such as the liver and kidneys. Therefore, a typical blood sample will only represent approximately 2 weeks of a given bird's diet (Craighead and Bedrosian, 2008). Blood samples typically consisted of approximately $100 \mu \mathrm{L}$ collected directly from the brachial vein into ammonium-heparinized plastic capillary tubes. Samples were stored on ice packs in the field until they could be transferred to a $-10^{\circ} \mathrm{C}$ freezer. Digestion and analysis of blood followed the same procedure as for feathers; however, the ratio of reagents used to digest the blood was 1:1 instead of approximately 3:1.

\section{Comparison to Previous Studies}

In 1997, the USFWS examined concentrations of $\mathrm{Cd}, \mathrm{Cu}, \mathrm{Hg}$, Se, and $\mathrm{Zn}$ in a small sample of Killdeer livers at Rio Rico North, a study site located midway between the Nogales International Wastewater Treatment Plant and Tumacacori National Historical Park (King and others, 1999). We used values found in literature to develop a feather:liver ratio for these heavy metals, which was then used to project relative sparrow liver concentrations (Llacuna and others, 1995; Agusa and others, 2005; Nam and others, 2005; Deng and others, 2007; Pan and others, 2008; Abduljaleel and others, 2012).

Estimated liver concentrations for Song Sparrows were then compared to measured liver concentrations reported in the literature for Killdeer. In 2008 and 2009, Kirkpatrick and others (2010) examined concentrations of $\mathrm{Cd}, \mathrm{Cr}, \mathrm{Cu}, \mathrm{Hg}, \mathrm{Ni}, \mathrm{Pb}$, Se, and Zn in blood of Abert's Towhees (Melozone aberti) and Yellow-breasted Chats (Icteria virens) at Tumacacori National Historical Park. Song Sparrow blood metal concentrations were compared directly to the average blood metal concentrations for Abert's Towhees and Yellow-breasted Chats.

\section{Sparrow Conditions}

Hematocrit Values.-Blood samples were centrifuged in a ZIPocrit portable microhematocrit centrifuge (LW Scientific ${ }^{\odot}$ ) for 30 seconds, and calipers were used to determine hematocrit values (the proportion of red blood cells in a given blood sample). Low hematocrit values may be an indication of reduced health condition, such as parasite or bacterial infection (Ots and others, 1998; Snoeijs and others, 2004).

Leukocyte Counts. - Thin blood smears were air dried and then fixed in a vial of 200-proof ethanol for 30-60 seconds. Smears were stained with a Giemsa stain solution for 30-60 minutes and then a light microscope was used to determine leukocyte counts (Bennett, 1970; Morishita and others, 1999; Houwen, 2000). Slides were observed until approximately 30,000 red blood cells were examined. All white blood cells (lymphocytes, monocytes, basophils, eosinophils, and heterophils) were lumped into one category (leukocytes) in order to reduce the possibility of misclassifying white blood cell type.

Body Conditions. - Avian body condition was determined based on obtained field measurements (mass and tarsus-metatarsus length). These methods are described in section, "Bird Capture and Processing.” 


\section{Statistical Analysis}

We used JMP 9.0 (SAS Institute Inc., 2010) to perform all statistical analyses. For individuals with heavy metal concentrations less than detection limits, we assigned a value equal to one-half the detection limit (Wong and others, 2002; Agusa and others, 2005). All concentrations were converted to parts per million and natural log-transformed (Ln), although all figures use back-transformed values.

We used two- and three-way analysis of variances (ANOVAs) to test for differences in mean concentrations of each focal heavy metal among sites for blood and feathers, respectively. Sex was considered a main factor for both, whereas feather age was included as a main factor only for feather analysis. This was done to account for increasing heavy metal concentrations as a result of external deposition that was not removed by vigorous washing. Feather age was entered into the model as the number of days from the first date of feather collection for that particular field season. All possible interactions were included in both models, with the exception of feather age*sex*site interaction, so as to avoid over-fitting the models. LSMeans Student's t-tests were then used afterward to determine how sites differed from one another in terms of mean concentration for each heavy metal. We used matchedpair t-tests for feather samples of 37 individuals and blood samples of 33 individuals captured in both 2011 and 2012 to determine if heavy metals are accumulating from one year to the next. Student's t-tests were used to determine overall differences in heavy metal concentrations between years.

White blood cells were analyzed as a proportion of total number of cells read for each blood smear. Proportions were natural log transformed and a two-way ANOVA with LSMeans Student's t-test was used afterward to look for differences in white blood cell proportions among the six field sites. Oneand two-way ANOVAs with LSMeans Student's t-tests also were used to test for differences in means of body mass residuals and hematocrit values, respectively, among sites. Body mass residuals were used as an index for body condition and were calculated by fitting a linear regression of body mass versus tarsus-metatarsus length for males and females separately. A larger residual above or below the line of regression indicates if an individual is above or below average body condition, respectively (Ots and others, 1998; Snoeijs and others, 2004).

\section{Results}

\section{Distributional Patterns and Inter-Annual Differences}

Feathers.-We collected 99 sparrow outer tail feathers in 2011 and 102 in 2012. Of the 21 focal heavy metals, 15 showed at least one significant difference among the six field sites in 2011 (table 1), and 16 showed at least one significant difference among the six field sites in 2012 (table 2). Thirty-seven individuals were captured during both years of this study, providing an opportunity to investigate if heavy metals are accumulating in tail feathers of the same individual over consecutive years. Of the 21 heavy metals examined, 7 were significantly higher in 2012 than in 2011, whereas the other 14 showed no significant differences between years (table 3). When all individuals were considered, as opposed to just recaptured individuals, concentrations of Ag, Al, Cd, Mg, Mn, Sr, and Tl were all higher in 2012 than in 2011, whereas concentrations of Cu, Hg, and Ni were all lower in 2012 than in 2011 (table 4). 
Blood.-Blood samples were collected from 94 Song Sparrows in 2011 and 113 in 2012. Five heavy metals showed at least one significant difference among the six field sites in 2011 (table 5) and 12 showed significant differences among sites in 2012 (table 6). Thirty-three individuals supplied blood samples in both 2011 and 2012, providing the opportunity to investigate if heavy metals are accumulating within the same individuals over multiple years. Of the 21 focal heavy metals examined, 14 were significantly higher in 2012 than in 2011, and one (Ni) was significantly lower in 2012 than in 2011 (table 7). When all adults were considered, 15 heavy metals showed significant differences between 2011 and 2012. Concentrations of Al, As, Cd, Cu, Fe, Hg, Mg, Mn, Mo, Pb, Sr, Tl, V, and Zn were all higher in 2011 than in 2012, whereas concentrations of Ni was lower in 2011 than in 2012 (table 8).

\section{Comparison to Previous Studies}

Estimated Song Sparrow liver concentrations for $\mathrm{Cu}, \mathrm{Cd}$, Se, and $\mathrm{Hg}$ at sites NIWWTP and TUMA were all lower than liver concentrations of these metals reported by King and others (1999) for Killdeer at Rio Rico North. Zn was the only metal higher in Song Sparrows than Killdeer (fig. 10). Blood concentrations of $\mathrm{Cr}$ and Ni for Song Sparrows at site TUMA were lower than blood concentrations of these metals reported by Kirkpatrick and others (2010) for Abert's Towhees and Yellow-breasted Chats. Cd showed similar concentrations between Abert's Towhees and Song Sparrows, but Yellow-breasted Chats were less than detection limits. $\mathrm{Pb}, \mathrm{Cu}$, and $\mathrm{Zn}$ concentrations were only slightly higher in Song Sparrows than in Abert's Towhees and Yellow-breasted Chats, whereas Hg and Se were two to six times higher in Song Sparrows than in Abert's Towhees and Yellowbreasted Chats (fig. 11).

\section{Sparrow Condition}

Hematocrit Values.-Hematocrit values were determined for 54 males and 28 females in 2011, and 65 males and 42 females in 2012. Red blood cell content in males averaged 50.15 and 51.05 percent in 2011 and 2012, respectively, whereas red blood cell content in females averaged 47.67 and 49.29 percent in 2011 and 2012, respectively (fig. 12). Although males have a significantly higher hematocrit values than females in 2011 (two-way ANOVA, $\mathrm{F}_{(1,80)}=6.67 \mathrm{p}=0.0119$ ), the difference was not significant in 2012 (two-way ANOVA, $\mathrm{F}_{(1,105)}=1.38, \mathrm{p}=0.2427$ ).

Leukocyte Count.-Blood smears were examined for 88 Song Sparrows across all field sites in 2011 and 115 in 2012. Between 25,520 and 46,255 cells were read per slide, with an average of approximately 31,500 cells. In 2011, average white blood cell counts were significantly higher at sites SOCR and NOWA than at all other sites (two-way ANOVA, $\mathrm{F}_{(5,82)}=5.12, \mathrm{p}=0.0004$ ). There was no significant difference among sites in 2012 (two-way ANOVA, $\mathrm{F}_{(5,109)}=1.01, \mathrm{p}=0.4142$; fig. 13). In general, the proportion of white blood cells were significantly higher in 2011 than in 2012 (two-way ANOVA, $F_{(5,197)}=8.98$, $\left.\mathrm{p}=0.0031\right)$.

Body Condition. - In 2011, body mass residuals were significantly higher at SOCA than at NIWWTP and TUMA, whereas body condition was significantly lower at TUMA than at all other sites, except NIWWTP (two-way ANOVA, $\mathrm{F}_{(5,82)}=4.07$, $\mathrm{p}=0.0023$; fig. 14). There were no significant differences among sites in 2012. 


\section{Discussion}

This study provides an understanding of how heavy metals are accumulating in a resident riparian bird species and what possible associations they may have had on condition.

\section{Distributional Patterns}

For feathers, concentrations of 15 heavy metals were significantly different among sites in 2011, and of 16 in 2012. For blood, concentrations of 5 heavy metals were significantly different among field sites in 2011, and of 12 in 2012. Generally, birds accumulated heavy metals in relation to their sources of pollution. Data were relatively consistent between 2011 and 2012 in terms of which sites showed the highest or lowest concentrations of metals, indicating that the sources of pollution did not change between years.

For most heavy metals, mean concentrations were lowest at our control site $\mathrm{LOCH}$, or were not significantly different from the site that showed the lowest mean concentration. This corroborates our prediction that this site, given that its location is at the headwaters of the Santa Cruz River in the rural San Rafael Grasslands and that it is upstream of any industry, would have the lowest heavy metal concentrations. However, mean concentrations were highest at site LOCH or were not significantly different from the site with the mean highest concentration of As, Ba, Fe (2011 only), Tl (2011 only), and Sr (2012 only). These heavy metals may be mobilized from natural sources given that the San Rafael Grasslands has a volcanic geology (Towne, 2003; Mora and others, 2007). Furthermore, they do not seem to be any cause for concern as they fall below or within range of average background concentrations.

NOWA was one of the sites with the highest concentrations of $\mathrm{Cu}, \mathrm{Cr}, \mathrm{Fe}, \mathrm{Mo}$, Sb, Se, and $\mathrm{U}$ in 2011 and 2012. Concentrations of As in feathers also were the highest at NOWA in 2012. Heavy metals in Nogales Wash are probably from both anthropogenic sources and natural deposits (because Nogales sits on a volcanic landscape). In particular, not only does Nogales Wash receive surface-water drainage, but it also receives water from leaking sewage or drinking water pipes, as well as random "fugitive flow" from both Nogales urban areas. Fugitive flow is wastewater that bypasses the collection and transport system to the Nogales International Wastewater Treatment Plant, allowing it to instead flow into Nogales Wash. Cu was the only heavy metal at Nogales Wash at very high concentrations. $\mathrm{Cu}$ concentrations were highest at site NOWA both years although elevated in feathers at all sites in 2011 and all sites but LOCH and TUMA in 2012. Although $\mathrm{Cu}$ is an essential mineral, overexposure can result in liver, kidney, or gastrointestinal disorders (Klaassen, 2001). Southern Arizona contains one of the nation's largest deposits of $\mathrm{Cu}$ (Long and others, 1998). Therefore, it is possible that birds in the upper Santa Cruz River watershed and especially NOWA may contain the highest concentrations due to upstream runoff or urban sources of $\mathrm{Cu}$ in the wash. The high blood concentration of Se at NOWA is likely a result of anthropogenic factors, such as runoff from industry.

Sites PLSP and SOCR are both located along Sonoita Creek, which receives runoff from abandoned mining areas in the Patagonia Mountains. The two sites are separated by Patagonia Lake, which may cause heavy metals in the upstream water (PLSP) to settle or precipitate out in the lake before reaching downstream (SOCR and through to the main Santa Cruz River channel). Both sites appeared to have similar concentrations for many of the focal heavy metals, although SOCR had a smaller sample size and usually did not differ statistically from other sites. Site PLSP often was not 
significantly different from any other site in 2011, also due to a small sample size. However, trends at site PLSP during 2011 were still similar to trends in 2012, which had a much larger sample size. In particular, concentrations of $\mathrm{Pb}$ and $\mathrm{Tl}$ were highest at site PLSP, whereas concentrations of $\mathrm{Pb}$ and $\mathrm{Hg}$ were high at site SOCR. Pb and Tl do not appear to exceed background concentrations; however, Hg in feathers did exceed background concentrations at site SOCR in 2011. Chronic exposure to Hg can result in neurological disorders (Kakkar and Jaffery, 2005), as well as cause reproductive effects (Heinz and Hoffman, 2003). Site SOCR likely receives elevated Hg concentrations as a result of gold mining in the Patagonia Mountains, because Hg is used to extract gold from ore (Malm and others, 1990). The fact that concentrations are lower at site PLSP than at site SOCR, which is downstream and separated from site PLSP by Patagonia Lake, might indicate that Hg undergoes a biotransformation to methylmercury in Patagonia Lake, which allows for bioaccumulation at the downstream site (Gardner and others, 1978). SOCR's small sample size also may be an important factor in its high mean concentration.

Mean concentrations were highest at the NIWWTP site, most notably for Cd and Ni. Mean concentrations of Mo also were one of the highest in 2011, and Cr both years, although they did not exceed background levels. However, Cd and Ni exceeded background concentrations in Song Sparrow feathers at the treatment plant. Cadmium is a non-essential mineral that can cause bone or kidney damage when exposure is high or long term. Both metals are also known carcinogens (Kakkar and Jaffery, 2005). The high Cd and Ni concentrations in feathers at the treatment plant were likely a result of industry in urban Nogales, as wastewater containing these metals was pumped from Nogales to the treatment plant.

Similar to sites NIWWTP and NOWA, TUMA had one of the highest concentrations of Cr in 2011 and 2012, and Mo in 2011 only. Moreover, mean concentrations of heavy metals were generally similar or significantly lower at TUMA than at NIWWTP and NOWA. Metal concentrations were never significantly greater at TUMA than at NIWWTP for any metal, and were only greater at TUMA than NOWA for Cd and Ni, likely due to its downstream location from the treatment plant. Metals that may be released in the effluent of treatment plant are likely at a lower concentration by the time it reaches TUMA, due to adsorption to sediments and settling. In 2011, concentrations of $\mathrm{Ni}$ in feathers were second highest at TUMA and exceeded background concentrations, which was likely an artifact of high Ni concentrations in water at the wastewater-treatment plant.

\section{Inter-Annual Differences}

Overall, concentrations of Ag, $\mathrm{Al}, \mathrm{Cd}, \mathrm{Mg}, \mathrm{Mn}, \mathrm{Sr}$, and $\mathrm{Tl}$ in feathers were significantly higher in 2012 than in 2011. While concentrations of $\mathrm{Cu}, \mathrm{Hg}$, and $\mathrm{Ni}$ in feathers were lower in 2012 than in 2011, they were still largely at concentrations exceeding literature values. However, blood concentrations were significantly higher for all metals except one (Ni) in 2011 than in 2012.

Song Sparrow molt occurs after breeding in the late summer (Arcese, 1989), therefore, a 1 year lag must be taken into account when relating blood to feathers. Feather samples collected in 2012 may be more representative of blood samples collected in 2011, rather than blood samples collected in 2012. Because heavy metal concentrations were higher in 2011 blood samples than in 2012 blood samples, it is difficult to say whether higher metal concentrations in feathers in 2012 are a result of higher dietary exposure in 2011, or if it is a result of temporal accumulation.

Nevertheless, heavy metal concentrations in blood and feathers sampled in both years were significantly higher in 2012. For blood, this might be indicative of tissue accumulation for these metals, as it is possible that organs constantly exposed to blood, such as liver and kidneys, build up higher concentrations of heavy metals over time. Because of the constant blood flow, metals stored in tissue 
can become mobilized and transfer back to the blood (Rattner and others, 2008). Therefore, higher concentrations in blood also may be indicative of higher concentrations in organs due to accumulation, as well as diet. Yet, because there is an overall decrease in metal concentrations between 2011 and 2012 (that is, when all individuals are taken into account, as opposed to just the subset of recaptured individuals), increased dietary exposure does not seem like a probable explanation for the increased blood concentrations of the 33 recaptured Song Sparrows. Similarly, the increased concentrations among these 33 individuals appear to provide evidence against major depuration between years. This information seems to suggest that temporal accumulation in feathers also is occurring, although successive years of feather collection would be necessary to provide stronger evidence.

\section{Comparison to Previous Studies}

In 1997, the USFWS concluded that $\mathrm{Al}, \mathrm{Cd}, \mathrm{Cu}, \mathrm{Hg}$, Se, and $\mathrm{Cr}$ did not pose a concern for birds in the upper Santa Cruz River watershed as concentrations in Killdeer livers fell within the average range. No other potentially harmful metals, such as Ni, were detected (King and others, 1999).

Mean concentrations of most heavy metals in Killdeer livers were higher than the estimated concentrations in Song Sparrow livers. Concentrations of $\mathrm{Al}, \mathrm{Cd}, \mathrm{Cu}, \mathrm{Hg}$, and Se in Killdeer livers collected at Rio Rico North, approximately $4.8 \mathrm{mi}$ downstream of the Nogales International Wastewater Treatment Plant, were higher than estimated liver concentrations for Song Sparrows sampled at NIWWTP and TUMA (approximately $10 \mathrm{mi}$ downstream of the treatment plant). This may be attributable to a facility upgrade at the wastewater-treatment plant in 2009. However, Zn concentrations were estimated to be higher for Song Sparrows at NIWWTP and TUMA than for Killdeer at Rio Rico North.

In 2008 and 2009, Kirkpatrick and others (2010) examined the extent of heavy metal exposure in the blood of Abert's Towhees and Yellow-breasted Chats at Tumacacori. They conclude that all metals are within the average range and heavy metal contamination does not pose a health risk for songbirds at Tumacacori National Historical Park. In general, this study agrees with the results of Kirkpatrick and others (2010), as most metals in Song Sparrow blood at TUMA were at concentrations similar to or less than Abert's Towhees and Yellow-breasted Chats (fig. 3). For example, As, Cr, and Ni concentrations are lower in Song Sparrows, whereas $\mathrm{Cd}, \mathrm{Pb}$, and $\mathrm{Sr}$ in both studies show similar concentrations. Concentrations of $\mathrm{Cu}, \mathrm{Hg}$, Se, and Zn were higher in Song Sparrows than in Abert's Towhees or Yellow-breasted Chats, suggesting that there may have been an increased uptake of these metals by birds at Tumacacori National Historical Park since 2008 and 2009. Although the difference for Cu, Hg, and Zn concentrations is rather moderate, it is nearly six times as large for Se.

Furthermore, given the increasing proposals of new mines that may affect the Santa Cruz River watershed (Myers, 2010), this study may prove to be an important source of baseline information for future studies. We provide a baseline of heavy metal data in birds to which accumulation-monitoring studies in the region may look to compare so as to examine how the extent of heavy metal accumulation has changed in birds following mine development.

\section{Sparrow Condition}

The effects of heavy metal exposure on avian health have been well documented. For example, some heavy metals have been associated with reduced body condition in wintering diving ducks off coastal California (Takekawa and others, 2002), whereas selenium can lead to reduce cell-mediated immunity and suppress immunocompetence at certain doses in Mallards (Anas platyrhynchos; Fairbrother and Fowles, 1990). Furthermore, overall white blood cell count and antibody production were reduced in lead-dosed Mallards (Trust and others, 1990; Rocke and Samuel, 1991; Fairbrother and others, 2004). 
Overall, the results of this study did not indicate any major health consequence to Song Sparrow condition in the upper Santa Cruz River watershed as a result of heavy metal exposure. Although a low hematocrit value can be indicative of reduced health, as it reveals the blood's oxygen-carrying capacity and nutritional status (Ots and others, 1998; Snoeijs and others, 2004; Kilgas and others, 2006), hematocrit values in 2011 and 2012 fell within the average range given for passerine birds (Llacuna and others, 1996; Kilgas and others, 2006; Potti, 2007; Geens and others, 2010). This suggests that either heavy metal exposure did not affect hematocrit values or that exposure was not enough to induce hematological affects. Hematocrit values generally were lower in females than in males, although this was only significant in 2011. Although this is contrary to some studies, in which hematocrit values were higher in female Great Tits (Parus major) than males (Ots and others, 1998; Kilgas and others, 2006), it is consistent with others that suggest hormonal differences between males and females result in hematocrit differences (Prinzinger and Misovic, 1994). Possibly along related lines, another suggestion for this result is that during nesting (when blood samples were collected), females have a lower immunocompetence as a trade-off for reproduction (Ots and Horak, 1996; Nordling and others, 1998; Hanssen and others, 2005).

For the most part, leukocyte count and body condition appear normal for birds in the upper Santa Cruz River watershed. There were no significant site differences in body mass residuals among sites in 2012, and there does not appear to be any clear pattern as to why birds at TUMA showed a particularly low body condition in 2011. Furthermore, leukocyte counts appear similar among most sites, although they are elevated at sites SOCR and NOWA in 2011. Although this cannot necessarily be attributed to heavy metal exposure, it is possible that the slightly enhanced immune response is a result of exposure to moderate concentrations of heavy metals (Eeva and others, 2005). However, because the overall health of birds appears normal, we have no reason to believe that heavy metals are currently affecting avian well-being in the region.

Although a heightened immune response as a result of moderate pollution levels may seem beneficial, it is important to keep in mind that it is an organism's defense mechanism. Not only is it very expensive energetically (Martin II and others, 2003), but a constant immune response also can be physically harmful and contribute to the formation of some diseases (Nathan and Ding, 2010). Continued study in the upper Santa Cruz River watershed would be necessary to know if the heightened immune response in 2011 was an isolated occurrence, or if it is a general trend over several years.

Although this study does not seem to show any major physical associations between chronic heavy metal exposure and condition, it is possible that there are unseen effects, such as at the molecular level. The development of differential gene expression assays to assess the immunological health of marine mammals provides a promising new technique for monitoring avian health. Environmental contaminants may affect genomic transcription via up- or down-regulation of certain genes, although often without observable effect, consequently altering protein production (Bowen and others, 2007). For example, American mink (Mustela vison) and sea otters (Enhydra lutris) exposed to petroleum oil show patterns in gene expression that are characteristic of oil exposure, despite a lack of any physical indication (Bowen and others, 2007, 2012). Future studies examining the effects of contaminants on wildlife should consider the evaluation of immune-regulating genes to provide insight into how different classes of chemicals, such as heavy metals, may or may not be compromising the health of free-living passerines or other wildlife (Bartosiewicz and others, 2001). 
Furthermore, this study was not able to look at the reproductive effects of heavy metal exposure. Future studies should consider examining the productivity of resident birds in the upper Santa Cruz River watershed in relation to heavy metal exposure. Nestlings may be a better indicator of environmental conditions because they are more sensitive than adults (Janssens and others, 2003). However, because most heavy metal concentrations in blood seem to be less than those found in other studies, whereas some feather concentrations seem to exceed concentrations found in the literature, it would be interesting for future studies to conduct a life span study to determine the degree to which long-term heavy metal accumulation affects longevity.

\section{Heavy Metals Exceeding Average Background Concentrations}

$\mathrm{Cd}, \mathrm{Cu}, \mathrm{Hg}, \mathrm{Ni}$, and Se are of most concern on the Santa Cruz River as they exceeded the mean plus twice the standard error for most study sites for feathers or blood, particularly sites NOWA, NIWWTP, and SOCR. Zn is of borderline concern because some sites seem slightly elevated above the threshold for feathers, but the mean concentrations at most sites are not significantly different.

Furthermore, $\mathrm{Zn}$ accumulation has increased in the region since previous studies. Although these metals are not necessarily present at toxic concentrations in the upper Santa Cruz River watershed (Kirkpatrick and others, 2010), they should be monitored in the future because they have the potential to cause harmful effects if they do accumulate to toxic levels. Furthermore, combinations of different contaminants can amplify an individual's susceptibility to different health effects (Kakkar and Jaffery, 2005), even if individual heavy metals do not exceed background concentrations.

\section{Conclusion}

Distributional patterns of heavy metal accumulation in birds reflected urban and mining sources of pollution among sites in the upper Santa Cruz River watershed. Certain potentially toxic metals, such as $\mathrm{Cd}, \mathrm{Ni}, \mathrm{Cu}, \mathrm{Hg}$, and Se, did exceed background concentrations found in the literature, particularly at sites NIWWTP, NOWA, and SOCR. However, concentrations of these metals have not reached what are presently considered toxic levels. Overall health of Song Sparrows at our study sites appear to be normal, as we did not find any strong evidence currently suggesting altered hematocrit values, white blood cell counts, or body condition in Song Sparrows due to heavy metal exposure. Furthermore, most heavy metal concentrations seem to have decreased over time following an upgrade to the wastewatertreatment plant, because concentrations at sites downstream of the treatment facility were lower in 2011-12 than in 1997 and 2008-09.

Birds may be accumulating, over multiple years, significantly greater burdens of heavy metals that do not currently exceed background concentrations. This is evidenced by higher heavy metal concentrations in 2012 blood and feather samples of recaptured individuals, although more years of data collection are necessary to verify this trend. Therefore, continued monitoring of avian exposure to heavy metals in the upper Santa Cruz River watershed, as well as future studies examining altered gene expression, productivity, and longevity of resident riparian birds, is highly recommended in order to provide a bigger picture of long-term accumulation and its effects on the region's wildlife. 


\section{References Cited}

Abduljaleel, S.A., Shuhaimi-otham, M., and Babji, A., 2012, Assessment of trace metal contents in Chicken (Gallus gallus domesticus) and Quail (Coturnix coturnix japonica) tissues from Selangor, Malaysia: Environmental Science \& Technology, v. 5, p. 441-451.

Agusa, T., Matsumoto, T., Ikemoto, T., Anan, Y., Kubota, R., Yasunaga, G., Kunito, T., Tanabe, S., Ogi, H., and Shibata, Y., 2005, Body distribution of trace elements in Black-tailed Gulls from Rishiri Island, Japan-Age-dependent accumulation and transfer to feathers and eggs: Environmental Toxicology and Chemistry, v. 24, p. 2,107-2,120.

Aldrich, J.W., 1985, Ecogeographical variation in size and proportions of Song Sparrows (Melospiza melodia): Wilson Bulletin, v. 97, p. 586-588.

Arcese, P., 1989, Intrasexual competition and the mating system in primarily monogamous birds-The case of the Song Sparrow: Animal Behavior, v. 38, p. 96-111.

Bartosiewicz, M., Penn, S., and Buckpitt, A., 2001, Applications of gene arrays in environmental toxicology-Fingerprints of gene regulation associated with cadmium chloride, benzo(a)pyrene, and trichloroethylene: Environmental Health Perspectives, v. 109, p. 71-74.

Bennett, G., 1970, Simple techniques for making avian blood smears: Canadian Journal of Zoology, v. 48, p. 585-586.

Bowen, L., Riva, F., Mohr, C., Aldridge, B., Schwartz, J., Miles, A.K., and Stott, J.L., 2007, Differential gene expression induced by exposure of captive mink to fuel oil-A model for the sea otter:

EcoHealth, v. 4, p. 298-309.

Bowen, L., Miles, A.K., Murray, M., Haulena, M., Tuttle, J., Van Bonn, W., Adams, L., Bodkin, J.L., Ballachey, B., Estes, J., Tinker, M.T., Keister, R., and Stott, J.L., 2012, Gene transcription in sea otters (Enhydra lutris) - Development of a diagnostic tool for sea otter and ecosystem health: Molecular Ecology Resources, v. 12, p. 67-74.

Braune, B.M., and Gaskin, D.E., 1987, Mercury levels in Bonaparte’s Gulls (Larus Philadelphia) during molt in the Quoddy region, New Brunswick, Canada: Archives of Environmental Contamination and Toxicology, v. 16, p. 539-549.

Burger, J., 1993, Metals in avian feathers-Bioindicators of environmental pollution, in Hodgson, E., ed., Review of environmental contamination: Raleigh, N.C., Toxicology Communications, Inc., p. 203-311.

Burger, J., and Gochfeld, M., 1997, Age differences in metals in the blood of Herring (Larus argentatus) and Franklin's (Larus pipixcan) Gulls: Archives of Environmental Contamination and Toxicology, v. 33, p. 436-440.

Burger, J., Schreiber, E.A., and Gochfeld, M., 1992, Lead, cadmium, selenium and mercury in seabird feathers from the tropical mid-pacific: Environmental Toxicology and Chemistry, v. 11, p. 815-822.

Craves, J.A., 1994, Passerines with deformed bills: North American Bird Bander, v. 19, p. 14-18.

Chastel, O., Weimerskirch, H., and Jouventin, P., 1995, Body condition and seabird reproductive performance-A study of three petrel species: Ecology, v. 76, p. 2,240-2,246.

Costa, R.A., Petronilho, J.M.S., Soares, A.M.V.M., and Vingada, J.V., 2011, The use of passerine feathers to evaluate heavy metal pollution in central Portugal: Bulletin of Environmental Contamination and Toxicology, v. 86, p. 352-356.

Craighead, D., and Bedrosian, B., 2008, Blood lead levels of Common Ravens with access to big-game offal: Journal of Wildlife Management, v. 72, p. 240-245.

Davis, A., and Arcese, P., 1999, An examination of migration in Song Sparrow using banding recovery data: North American Bird Bander, v. 24, p. 124-128.

Dauwe, T., Bervoets, L., Janssens, E., Pinxten, R., Blust, R., and Eens, M., 2002, Great and Blue Tit feathers as biomonitors for heavy metal pollution: Ecological Indicators, v. 1, p. 227-234. 
Deng, H., Zhang, Z., Chang, C., and Wang, Y., 2007, Trace metal concentration in Great Tit (Parus major) and Greenfinch (Carduelis sinica) at the Western Mountains of Beijing, China: Environmental Pollution, v. 148, p. 620-626.

Dmowski, K., 2000, Environmental monitoring of heavy metals with magpie (Pica pica) feathers-An example of Polish polluted and control sites, in Markert, B., and Friese, K., eds., Trace elementsTheir distribution and effects in the environment: Amsterdam, Netherlands, Elsevier Science, p. 455477.

Eens, M., Pinxten, R., Verheyen, R.F., Blust, R., and Bervoets, L., 1999, Great and Blue Tits as indicators of heavy metal contamination in terrestrial ecosystems: Ecotoxicology and Environmental Safety, v. 44, p. 81-85.

Eeva, T., Hasselquis, D., Langefors, A., Tummeleht, L., Nikinmaa, M., and Ilmonen, P., 2005, Pollution related effects on immune function and stress in a free-living population of pied flycatcher (Ficedula hypoleuca): Journal of Avian Biology, v. 36, p. 405-412.

Evers, D.C., Kaplan, J.D., Meyers, M.W., Reaman, P.S., Braselton, W.E., Major, A., Burgess, N., and Scheuhammer, A.M., 1998, Geographic trend in mercury measured in Common Loon feathers and blood: Environmental Toxicology and Chemistry, v. 17, p. 173-183.

Fairbrother, A., and Fowles, J., 1990, Subchronic effects of sodium selenite and selenomethionine on several immune-functions in mallards: Archives of Environmental Contamination and Toxicology, v. 19, p. 836-844.

Fairbrother, A., Smits, J., and Grasman, K.A., 2004, Avian immunotoxicology: Journal of Toxicology and Environmental Health, Part B, v. 7, p. 105-137.

Gardner, W.S., Kendall, D.R., Odom, R.R., Windom, H.L., and Stephens, J.A., 1978, The distribution of methyl mercury in a contaminated salt marsh ecosystem: Environmental Pollution, v. 15, p. 243-251.

Geens, A., Dauwe, T., Bervoets, L., Blust, R., and Eens, M., 2010, Haematological status of wintering great tits (Parus major) along a metal pollution gradient: Science of the Total Environment, v. 408, p. 1,174-1,179.

Golden, N.H., Rattner, B.A., McGowan, P.C., Parsons, K.C., and Ottinger, M.A., 2003, Concentrations of metals in feathers and blood of nestlings Black-crowned Night-Herons (Nycticorax nycticorax) in Chesapeake and Delaware Bays: Bulletin of Environmental Contamination and Toxicology, v. 70, p. 385-393.

Grasman, K.A., 2002, Assessing immunological function in toxicological studies of avian wildlife: Integrative and Comparative Biology, v. 42, p. 34-42.

Hanssen, S.A., Hasselquist, D., Folstad, I., and Erikstad, K.E., 2005, Cost of reproduction in a long-lived bird-Incubation effort reduces immune function and future reproduction: Proceedings of the Royal Society B-Biological Sciences, v. 272, p. 1,039-1,046.

Heinz, G.H., and Hoffman, D.J., 2003, Embryotoxic thresholds of mercury-Estimates from individual mallard eggs: Archives of Environmental Contamination and Toxicology, v. 44, p. 257-264.

Houwen, B., 2000, Blood film preparation and staining procedures: Laboratory Hematology, v. 6, p. 1-7.

Janssens, E., Dauwe, T., Bervoets, L., and Eens, M., 2001, Heavy metals and selenium in feathers of Great Tits (Parus major) along a pollution gradient: Environmental Toxicology and Chemistry, v. 20, p. 2,815-2,820.

Janssens, E., Dauwe, T., Pinxten, R., Bervoets, L., Blust, R., and Eens, M., 2003, Effects of heavy metal exposure on the condition and health of nestlings of the great tit (Parus major), a small songbird species: Environmental Pollution, v. 126, p. 267-274.

Johnson, R.R., Haight, L.T., and Simpson, J.M., 1977, Endangered species vs. endangered habitats-A concept, in Johnson, R.R., and Jones, D.A., eds., Importance, preservation, and management of riparian habitat—A symposium: Fort Collins, Colo., U.S. Forest Service, p. 68-79. 
Kahle, S., and Becker, P.H., 1999, Bird blood as bioindicator for mercury in the environment: Chemosphere, v. 39, p. 2,451-2,457.

Kakkar, P., and Jaffery, F.N., 2005, Biological markers for metal toxicity: Environmental Toxicology and Pharmacology, v. 19, p. 335-349.

Kilgas, P., Mänd, R., Mägi, M., and Tilgar, V., 2006, Hematologial parameters in brood-rearing great tits in relation to habitat, multiple breeding, and sex: Comparative Biochemistry and Physiology, Part A, v. 144, p. 224-231.

King, K.A., Zaun, J.Z., and Velasco, L.A., 1999, Contaminants as a limiting factor of fish and wildlife populations in the Santa Cruz River: Phoenix, Ariz., Project \#22410-1130-2F35, U.S. Fish and Wildlife Service, Regions 2 Contaminants Program.

Kirkpatrick, C., Conway, C.J., and LaRoche, D., 2009, Effects of ground water withdrawal on avian abundance and species richness in riparian areas of national parks in the desert southwest: Tucson, Ariz., U.S. Geological Survey, Wildlife Research Report \#2009-07, Arizona Cooperative Fish and Wildlife Research Unit.

Kirkpatrick, C., Conway, C.J., LaRoche, D., and Robinson, G., 2010, The influence of water quality on the health of riparian bird communities in Arizona: Tucson, Ariz., U.S. Geological Survey, Arizona Cooperative Fish and Wildlife Research Unit, Wildlife Research Report \#2009-03.

Klaassen, C.D., 2001, Casarett and Doull's Toxicology—The Basic Science of Poisons (6th ed.): New York, McGraw-Hill, 1,275 p.

Knopf, F.L., Johnson, R.R., Rich, T., Samson, F.B., and Szaro, R.C., 1988, Conservation of riparian ecosystems in the United States: The Wilson Bulletin, v. 100, p. 272-284.

Lane, O., Brenes, O., Doherty, P., Elizondo, P., Taylor, R., and Rinker, B., 2012, Heavy metals screening in feathers of resident birds and neotropical migrants at selected sites in Costa Rica and Panama: Gorham, Maine, Biodiversity Research Institute, accessed February 27, 2014, at www.reservaplayatortuga.org/pdf/metalbirds.pdf.

Llacuna, S., Gorriz, A., Riera, M., and Nadal, J., 1996, Effects of air pollution on hematological parameters in passerine birds: Archives of Environmental Contamination and Toxicology, v. 31, p. $148-152$.

Llacuna, S., Gorriz, A., Sanpera, C., and Nadal, J., 1995, Metal accumulation in three species of passerine birds (Emberiza cia, Parus, major, and Turdus merula) subjected to air pollution from a coal-fired power plant: Archives of Environmental Contamination and Toxicology, v. 28, p. 298-303.

Locke, L.N., and Bagley, G.E., 1967, Lead poisoning in a sample of Maryland Mourning Doves: Journal of Wildlife Management, v. 31, p. 515-518.

Long, K.R., DeYoung, J.H., and Ludington, S.D., 1998, Database of significant deposits of gold, silver, copper, lead, and zinc in the United States, Part A-Database description and analysis: U.S. Geological Survey Open-File Report 98-206A, http://pubs.er.usgs.gov/publication/ofr98206AB.

Malm, O., Pfeiffer, W.C., Souza, C.M.M., Reuther, R., 1990, Mercury pollution due to gold mining in the Madeira River basin, Brazil: Ambio, v. 19, p. 11-15.

Martin II, L.B., Scheuerlein, A., and Wikelski, M., 2003, Immune activity elevates energy expenditure of house sparrows - A link between direct and indirect costs?: Proceedings of the Royal Society BBiological Sciences, v. 270, p. 153-158.

Martinez-Lopez, E., Maria-Mojica, P., Martinez, J.E., Calvo, J.F., Romero, D., and Garcia-Fernandez, A.J., 2005, Cadmium in feathers of adults and blood of nestlings of three raptor species from a nonpolluted Mediterranean forest, southeastern Spain: Bulletin of Environmental Contamination and Toxicology, v. 74, p. 477-484.

Matz, A.C., and Rocque, D.A., 2007, Contaminants in Lesser Scaup eggs and blood from Yukon Flats National Wildlife Refuge, Alaska: Condor, v. 109, p. 852-861. 
MØller, A.P., Christe, Ph., ErrizØe, J., and Mavarez, J., 1998, Condition, disease and immune defense: Oikos, v. 83, p. 301-306.

Mora, M.A., Taylor, R.J., and Brattin, B.L., 2007, Potential ecotoxicological significance of elevated concentrations of strontium in eggshells of passerine birds: Condor, v. 109, p. 199-205.

Morrissey, C.A., Bendell-Young, L.I., and Elliott, J.E., 2005, Assessing trace-metal exposure to American Dippers in Mountain Streams of southwestern British Columbia, Canada: Environmental Toxicology and Chemistry, v. 24, p. 836-845.

Morishita, T.Y., Aye, P.P., Ley, E.C., and Harr, B.S., 1999, Survey of pathogens and blood parasites in free-living passerines: Avian Diseases, v. 43, p. 549-552.

Myers, T., 2010, Technical memorandum review of the proposed Rosemont Ranch Mine Hydrogeologic Analysis and Groundwater Model: Prepared for Pima County and Pima County Regional Flood Control District, $41 \mathrm{p}$.

Nam, D.-H., Anan, Y., Ikemoto, T., Okabe, Y., Kim, E.-Y., Subramanian, A.K., and others, 2005, Specific accumulation of 20 trace elements in Great Cormorants (Phalacrocorax carbo) from Japan: Environmental Pollution, v. 134, p. 503-514.

Nathan, C., and Ding, A., 2010, Nonresolving inflammation: Cell, v. 140, p. 871-882.

Norman, L.M., Gray, F., Guertin, D.P., and Wissler, C., 2008, Analysis of a watershed model of soil and waste rock-Using GIS to predict and track the fate of acid-mine drainage and impacts on surface water quailty in historic ghost towns of southeast Arizona: Environmental Monitoring and Assessment, v. 145, p. 145-157.

Nordling, D., Andersson, M., Zohari, S., and Gustafsson, L., 1998, Reproductive effort reduces specific immune response and parasite resistance: Proceedings of the Royal Society Bulletin, v. 265, p. 12911298.

Osofsky, A., Jowett, P.L.H., Hosgood, G., and Tully, T.N., 2001, Determination of normal blood concentrations of lead, zinc, copper, and iron in Hispaniolan Amazon Parrots (Amazona ventralis): Journal of Avian Medicine and Surgery, v. 15, p. 31-36.

Ots, I., and Horak, P., 1996, Great tits Parus major trade health for reproduction: Proceedings of the Royal Society Bulletin, v. 263, p. 1,443-1,447.

Ots, I., Murumagi, A., and Horak, P., 1998, Haematological health state indices of reproducing Great Tits - methodology and sources of natural variation: Functional Ecology, v. 12, p. 700-707.

Pan, C., Zheng, G., and Zhang, Y., 2008, Concentrations of metals in liver, muscle and feathers of Tree Sparrow-Age, inter-clutch variability, gender, and species differences: Bulletin of Environmental Contamination and Toxicology, v. 81, p. 558-560.

Potti, J., 2007, Variation in the hematocrit of a passerine bird across life stages is mainly of environmental origin: Journal of Avian Biology, v. 38, p. 726-730.

Prinzinger, R., and Misovic, A., 1994, Blood of birds-An allometric review of its components: Journal of Ornithology, v. 135, p. 133-166.

Ralph, C.J., Geupel, G.R., Pyle, P., Martin, T.E., and DeSante, D.F., 1993, Handbook of field methods for monitoring landbirds: USDA Forest Service/UNL Faculty Publications, Paper 105, 41 p., accessed February 27, 2014, at http://digitalcommons.unl.edu/usdafsfacpub/105.

Rattner, B.A., Golden, N.H., Toschik, P.C., McGowan, P.C., and Custer, T.W., 2008, Concentrations of metals in blood and feathers of nestling Ospreys (Pandion haliaetus) in Chesapeake and Delaware Bays: Archives of Environmental Contamination and Toxicology, v. 54, p. 114-122.

Rich, T.D., Beardmore, C.J., Berlanga, H., Blancher, P.J., Bradstreet, M.S.W., Butcher, G.S., Demarest, D.W., Dunn, E.H., Hunter, W.C., Iñigo-Elias, E.E., Kennedy, J.A., Martell, A.M., Panjabi, A.O., Pashley, D.N., Rosenberg, K.V., Rustay, C.M., Wendt, J.S., and Will, T.C., 2004, Partners in FlightNorth American Landbird conservation plan: Ithaca, N.Y., Cornell Lab of Ornithology, Partners in Flight web site, accessed February 27, 2014, at http://www.partnersinflight.org/cont_plan/. 
Rocke, T.E., and Samuel, M.D., 1991, Effects of lead shot ingestion on selected cells of the Mallard immune system: Journal of Wildlife Diseases, v. 27, p. 1-9.

SAS Institute Inc., 2010, JMP Version 9: Cary, N.C., SAS Institute Inc..

Snoeijs, T., Dauwe, T., Pinxten, R., Vandersande, F., and Eens, M., 2004, Heavy metal exposure affects the humoral immune response in a free-living small songbird, the Great Tit (Parus major): Archives of Environmental Contamination and Toxicology, v. 46, p. 399-404.

Sonoran Institute, 2007, Sustainable Water Management-Guidelines for meeting needs of people and nature in the arid west: Sonoran Institute, p. 52.

http://sonoraninstitute.org/component/docman/doc_details/1433-sustainable-water-managementguidelines-for-meeting-the-needs-of-people-and-nature-in-the-arid-west-06152007.html? Itemid=3.

Takekawa, J.Y., Wainwright-De La Cruz, S.E., Hothem, R.L., and Yee, J., 2002, Relating body condition to inorganic contaminant concentrations of diving ducks wintering in coastal California: Archives of Environmental Contamination and Toxicology, v. 42, p. 60-70.

Thompson, D.R., and Dowding, J.E., 1999, Site-specific heavy metal concentrations in blood of South Island Pied Flycatchers (Haematopus ostralegus finschi) from the Aukland region, New Zealand: Marine Pollution Bulletin, v. 38, p. 202-206.

Towne, D.C., 2003, Ambient groundwater quality of the San Rafael Basin-A 2002 baseline study: Arizona Department of Environmental Quality Open-File Report 2003-01, 42 p.

Trust, K.A., Miller, M.W., Ringelman, J.K., and Orme, I.M., 1990, Effects of ingested lead on antibody production in mallards (Anas platyrhynchos): Journal of Wildlife Disease, v. 26, p. 316-322.

Turner, W., 2001, The 2001 MAPS, Monitoring Avian Productivity and Survivorship, Season at Tumacácori National Historical Park, AZ: Final Report, U.S. National Park Service Desert Southwest CESU in-house report to Tumacacori NHP.

Van Loveren, H., Ross, P.S., Osterhaus, A.D.M.E., and Vos, J.G., 2000, Contaminant-induced immunosuppression and mass mortalities among harbor seals: Toxicology Letters, v. 112-113, p. 319-324.

van Wyk, E., van der Bank, F.H., Verdoon, G.H., and Hofmann, D., 2001, Selected mineral and heavy metal concentrations in blood and tissues of vultures in different regions of South Africa: South African Journal of Animal Science, v. 31, p. 57-63.

Wayland, M., Garcia-Fernandez, A.J., Neugebauer, E., and Gilchrist, H.G., 2001, Concentrations of cadmium, mercury and selenium in blood, liver, and kidney of Common Eider ducks from the Canadian arctic: Environmental Monitoring and Assessment, v. 71, p. 255-267.

Webb, R.H., and Leake, S.A., 2006, Ground-water surface-water interactions and long-term change in riverine riparian vegetation in the southwestern United States: Journal of Hydrology, v. 320, p. 302323.

Winter, S., and Streit, B., 1992, Organochlorine compounds in a three-step terrestrial food chain: Chemosphere, v. 24, p. 1,765-1,774.

Wong, S.C., Li, X.D., Zhang, G., Qi, S.H., and Min, Y.S., 2002, Heavy metals in agricultural soils of the Pearl River Delta, South China: Environmental Pollution, v. 119, p. 33-44. 


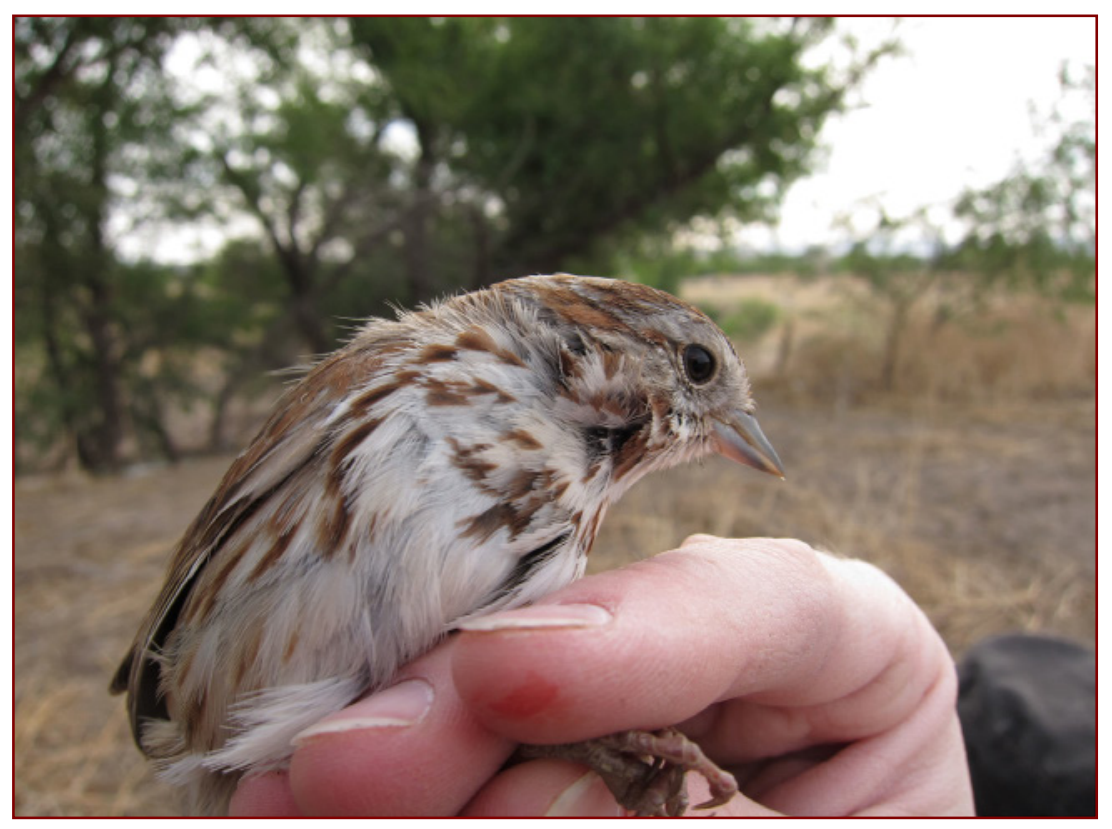

Figure 1. A Song Sparrow (Melospiza melodia) shortly after being captured downstream of the outfall at the Nogales International Wastewater Treatment Plant, southern Arizona.

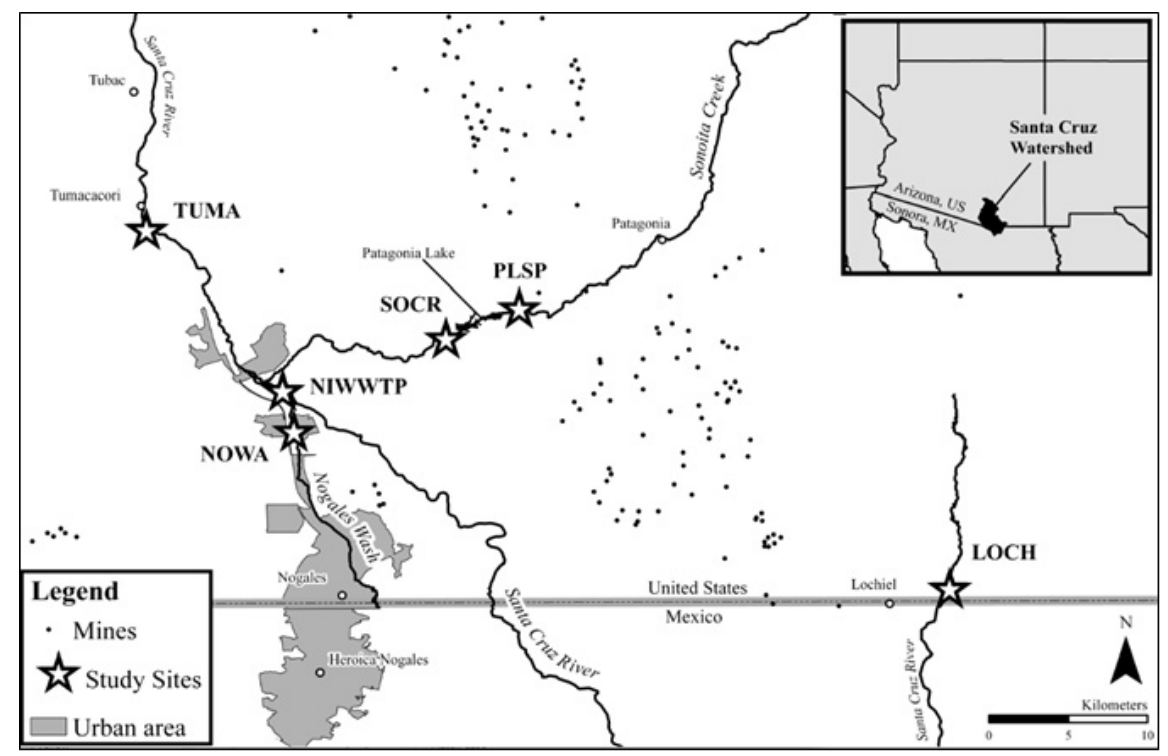

Figure 2. Schematic showing locations (latitude 313833; longitude 1109158) of six study sites in the upper Santa Cruz River watershed, southern Arizona, 2011-12. LOCH, Lochiel (San Rafael Grasslands-control site); NOWA, Nogales Wash; PLSP, Sonoita Creek (above Patagonia Lake); SOCR, Sonoita Creek (below Patagonia Lake); NIWWTP, Nogales International Wastewater Treatment Plant; TUMA, Tumacacori National Historical Park. 


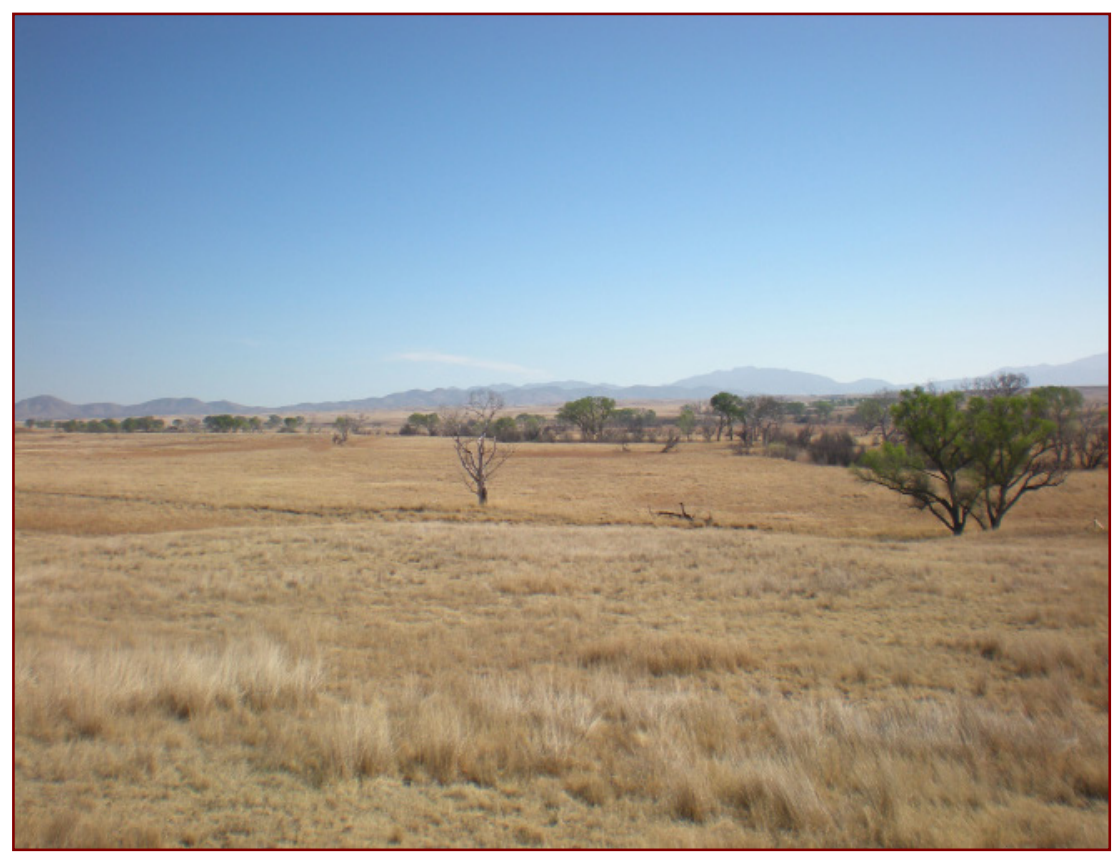

Figure 3. Study site at the headwaters of the Santa Cruz River (latitude 313833; longitude 1106275) east of Lochiel, southern Arizona, in the San Rafael Grasslands. Lochiel is our control site because of the upstream location from potential sources of pollution and rural populations.

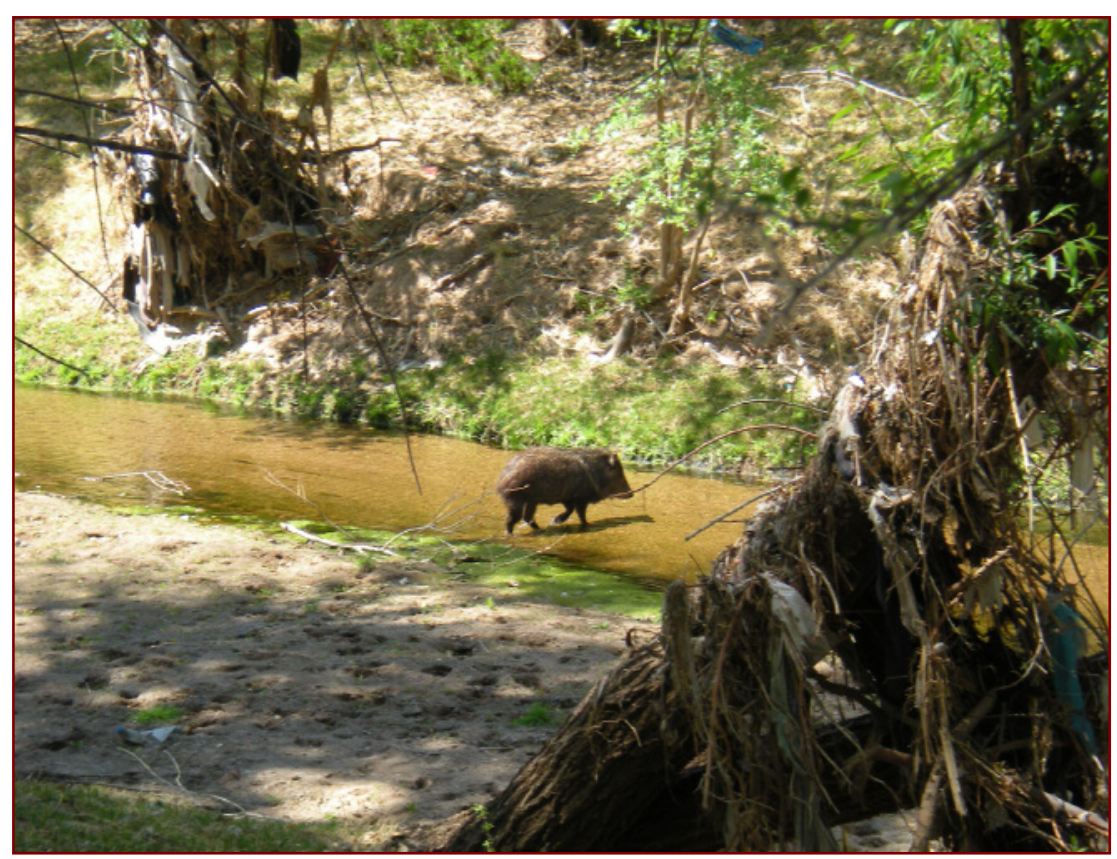

Figure 4. A Javelina (Pecari tajacu) crossing our study site at Nogales Wash, southern Arizona. Nogales Wash receives runoff, including organic and inorganic contaminants, from the cities of Nogales, Sonora and Nogales, Arizona. 


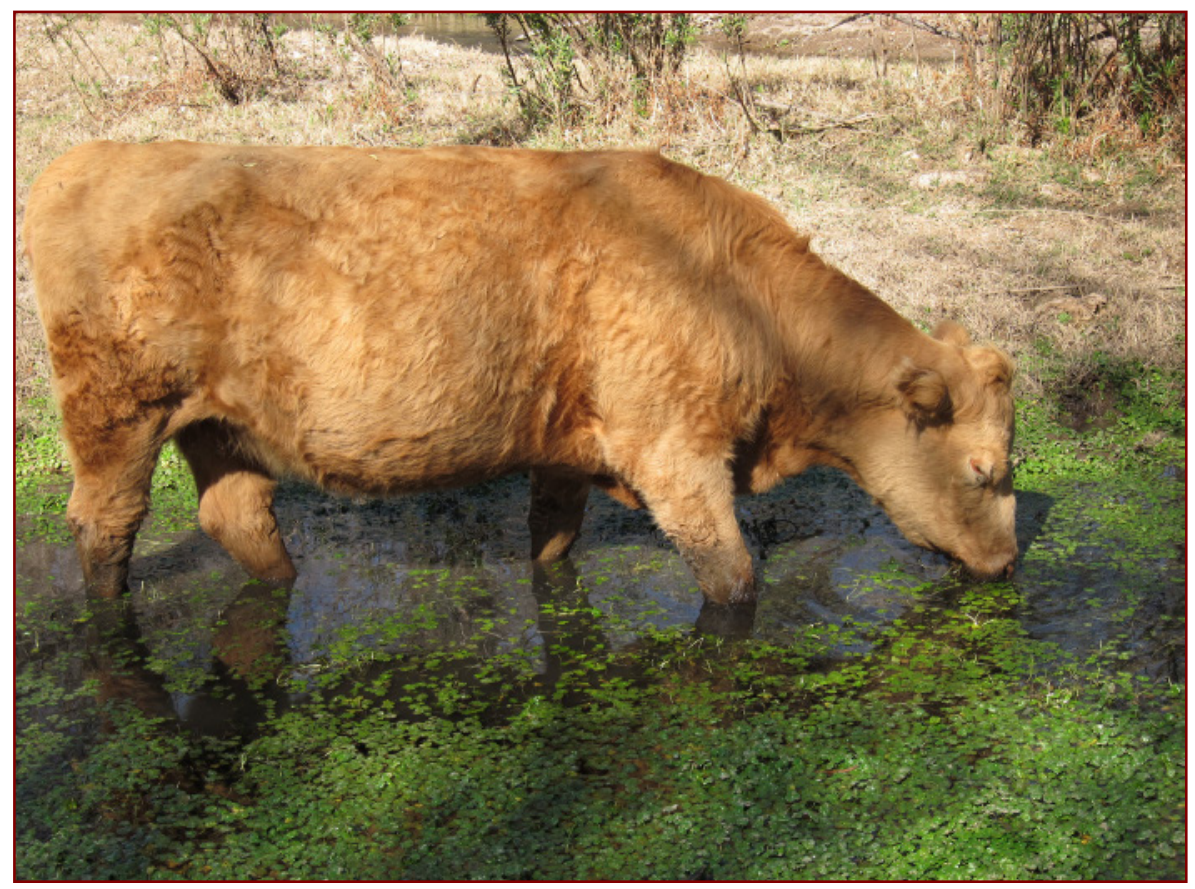

Figure 5. A cow drinks water from one of our study sites along Sonoita Creek (latitude 313500; longitude 1108437), near Patagonia Lake, southern Arizona. Sonoita Creek receives runoff from abandoned mining areas in the Patagonia Mountains.

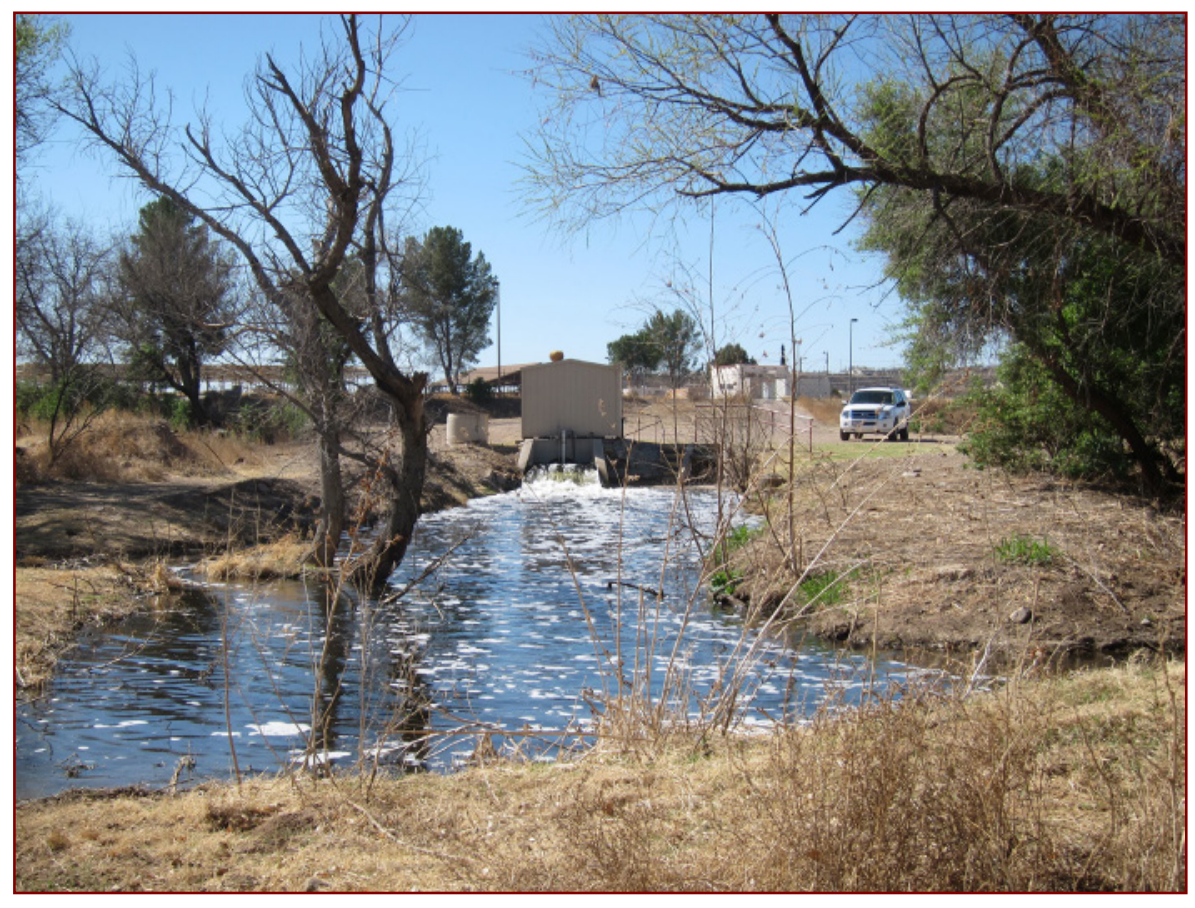

Figure 6. Our study site at the outfall of the Nogales International Wastewater Treatment Plant in southern Arizona. Song Sparrows (Melospiza melodia) were captured at locations downstream of the effluent release. 


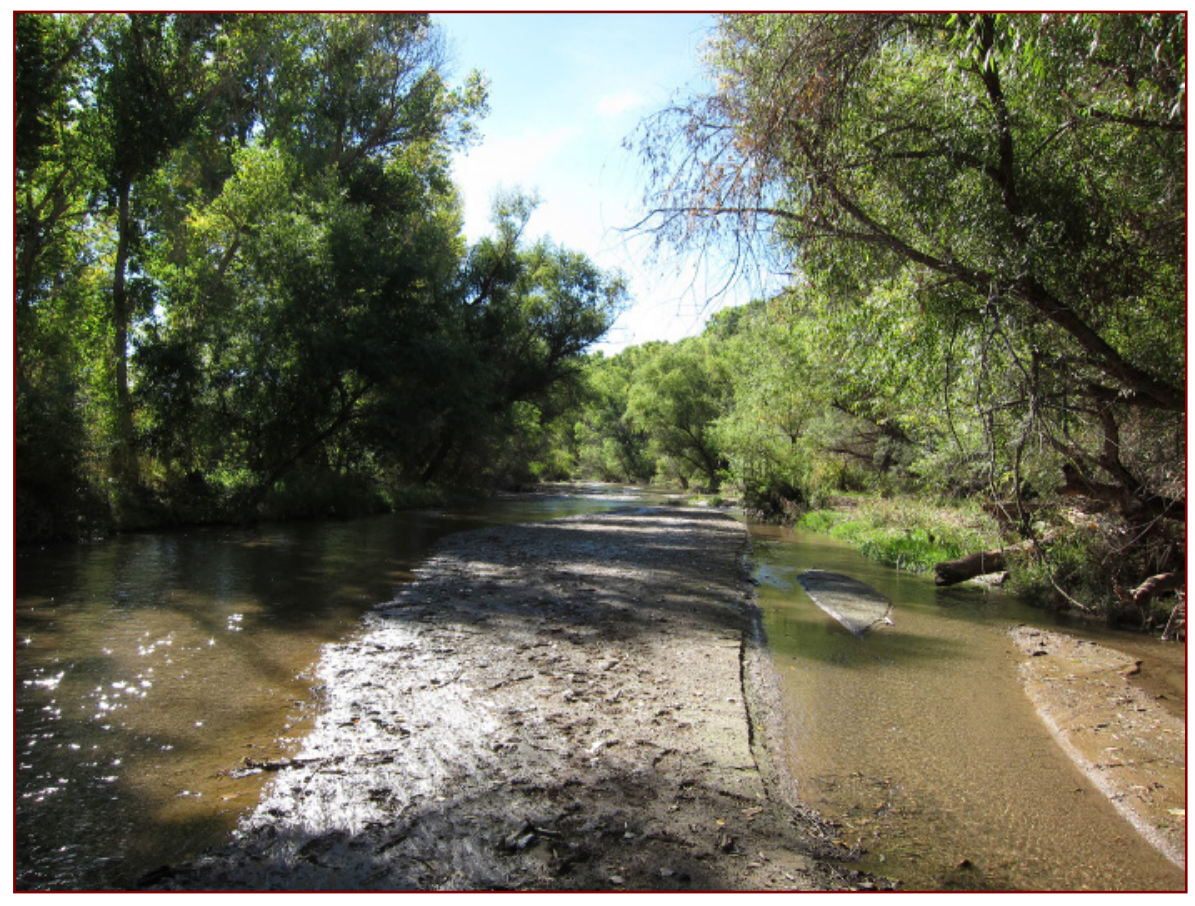

Figure 7. Santa Cruz River at Tumacacori National Historical Park (latitude 315500; longitude 1100600, southern Arizona. Tumacacori is the location of our most downstream study site.

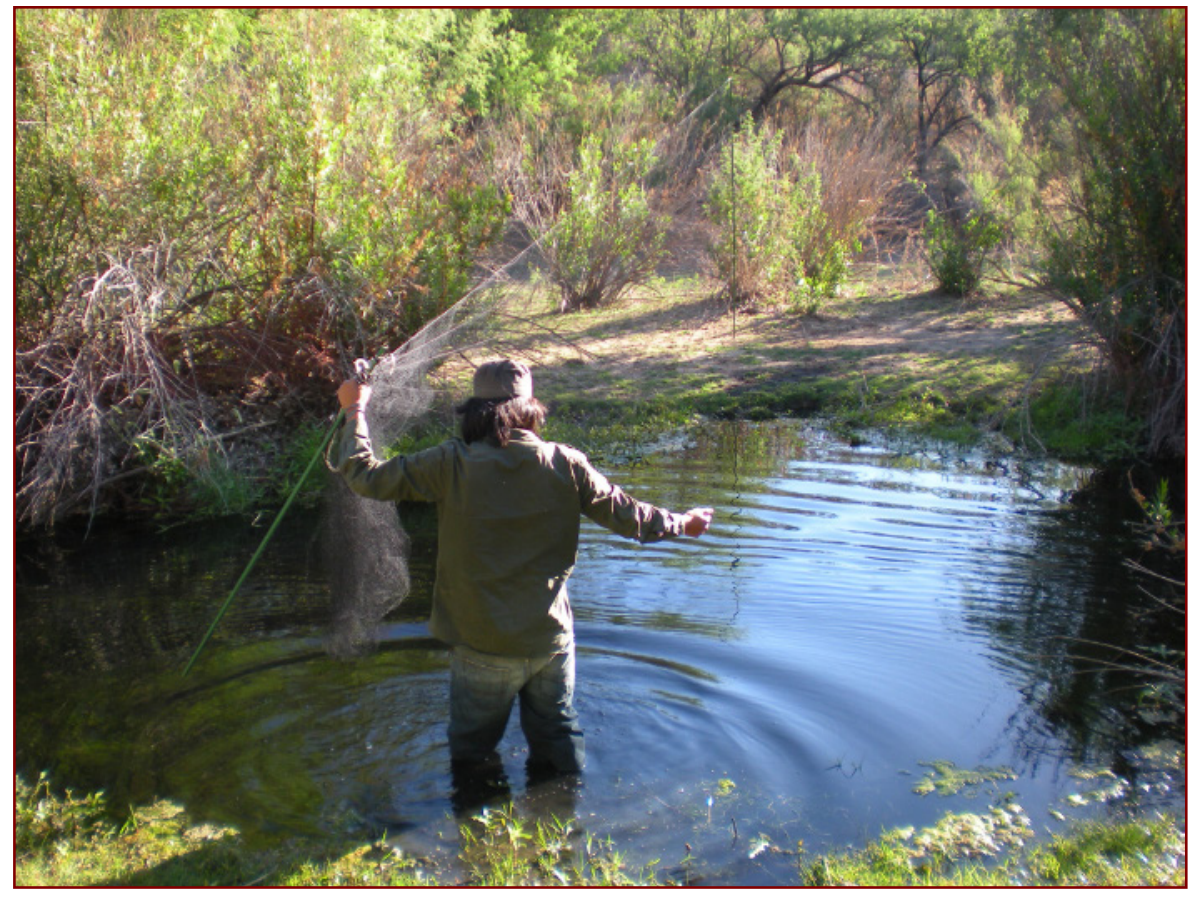

Figure 8. A field technician sets up a mist net across Sonoita Creek, below Patagonia Lake, southern Arizona, to help capture Song Sparrows (Melospiza melodia). 


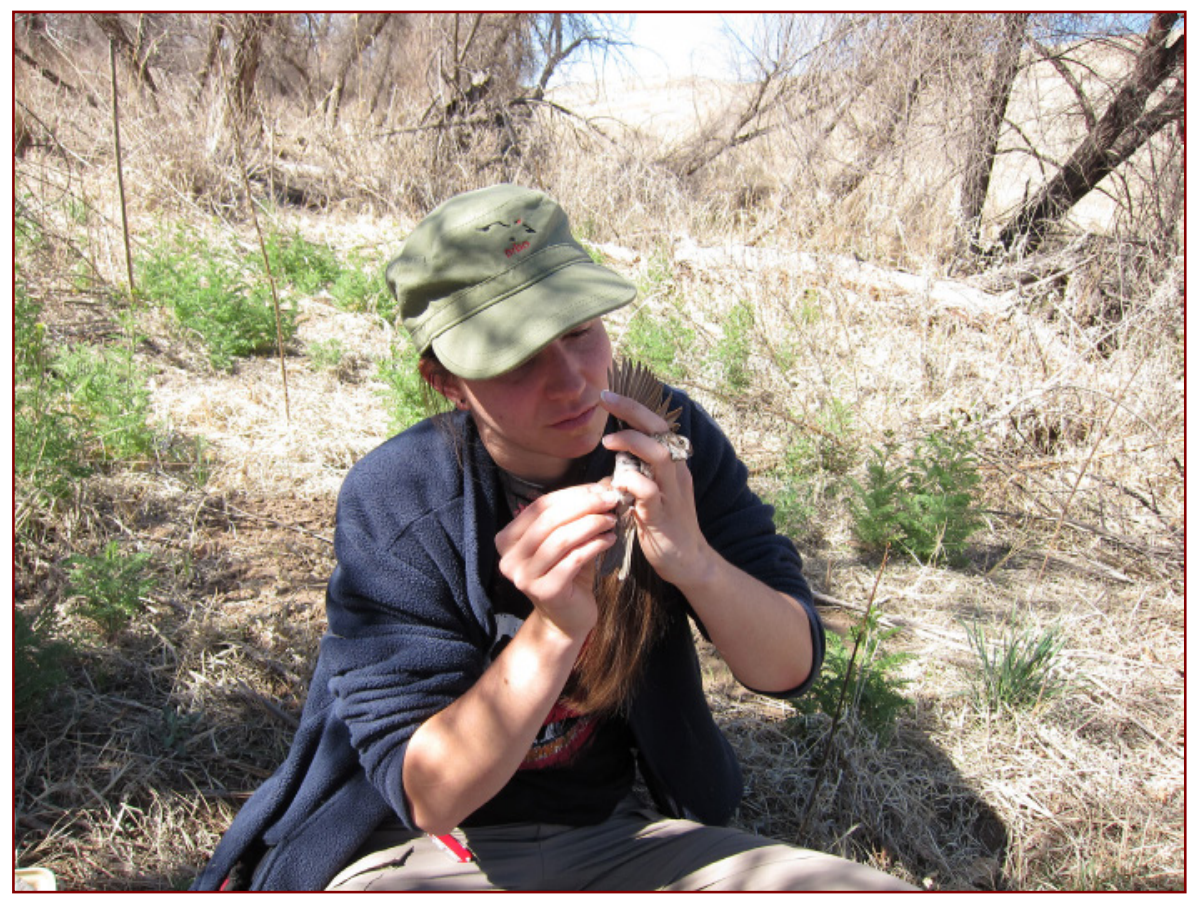

Figure 9. A field technician draw blood from a Song Sparrow (Melospiza melodia) at our control site, Lochiel (LOCH), southern Arizona. 


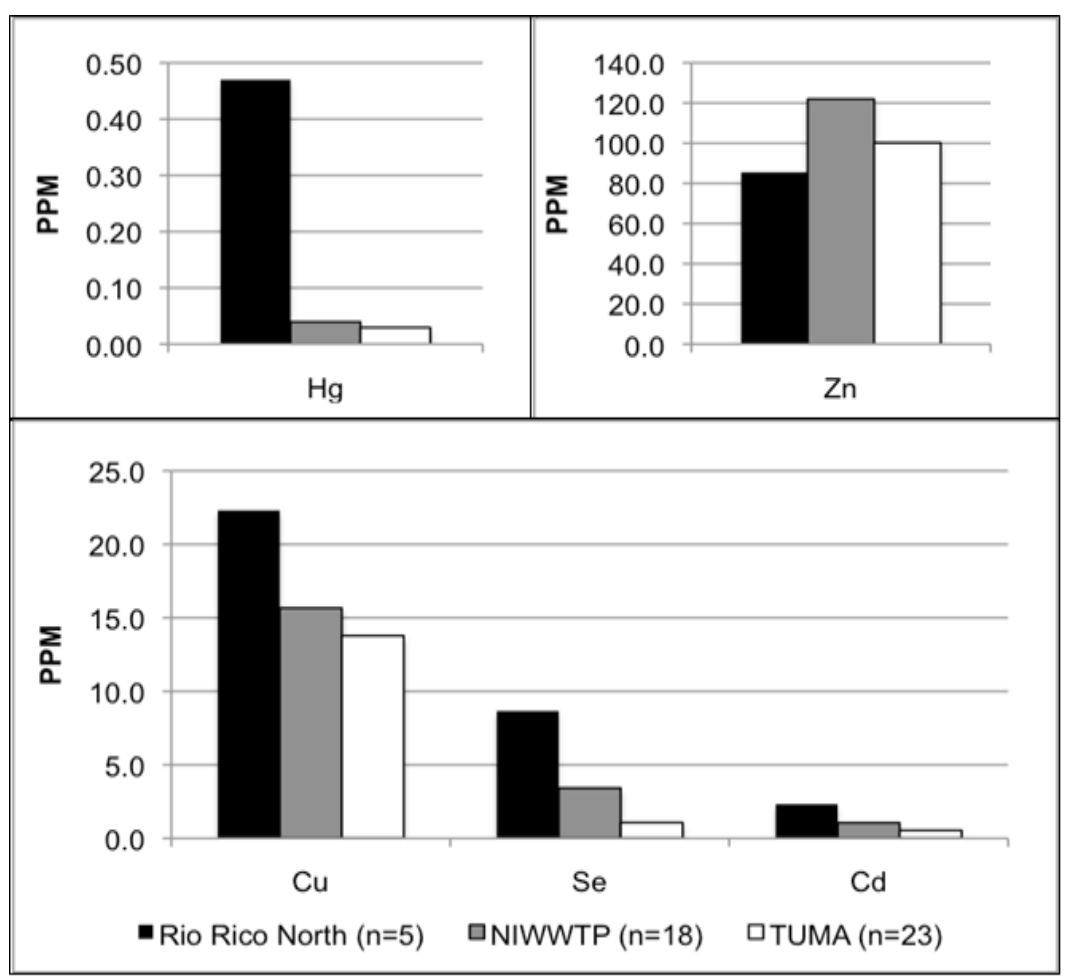

Figure 10. Comparison of the heavy metals from birds in the1997 U.S. Fish and Wildlife Service study at Rio Rico North site (King and others, 1999) with the present study at sites Nogales International Waste Water Treatment Plant (NIWWTP) and Tumacacori National Historical Park (TUMA), in southern Arizona. Presented are mean concentrations in parts per million (PPM) of mercury (Hg), zinc (Zn), copper (Cu), selenium (Se), and cadmium $(\mathrm{Cd})$ in livers of Killdeer (Charadrius vociferous) at Rio Rico North and Song Sparrows (Melospiza melodia) at sites NIWWTP and TUMA. Concentrations for Killdeer are observed, whereas concentrations for Song Sparrows (Melospiza melodia) are estimated based on observed feather concentrations and values found in the literature. 


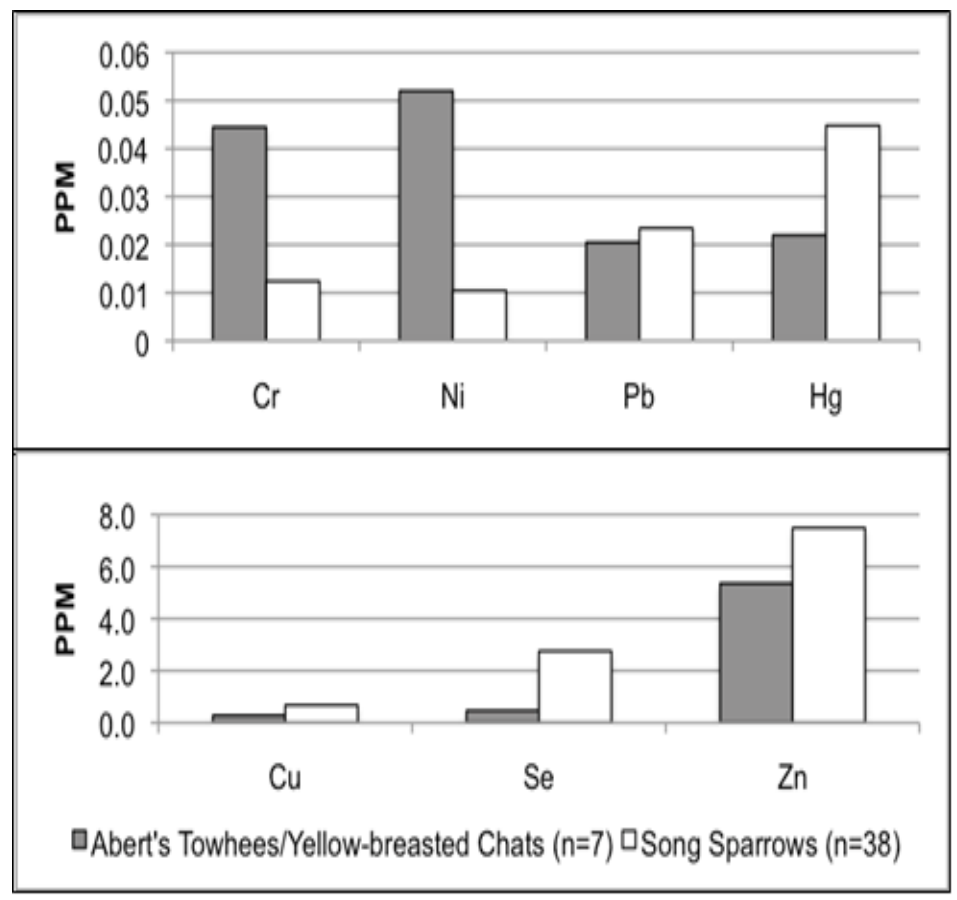

Figure 11. Comparison of heavy metals in Abert's Towhees (Melozone aberti) and Yellow-breasted Chats (Icteria virens) from the Kirkpatrick and others (2010) study with Song Sparrows (Melospiza melodia) in the present study. Presented are mean concentrations in parts per million (PPM) of chromium ( $\mathrm{Cr}$ ), nickel (Ni), lead (Pb), mercury $(\mathrm{Hg})$, selenium $(\mathrm{Se})$, zinc $(\mathrm{Zn})$, and copper $(\mathrm{Cu})$ in blood of birds at Tumacacori National Historical Park, Arizona. Mean concentrations for Song Sparrows were averaged between 2011 and 2012.

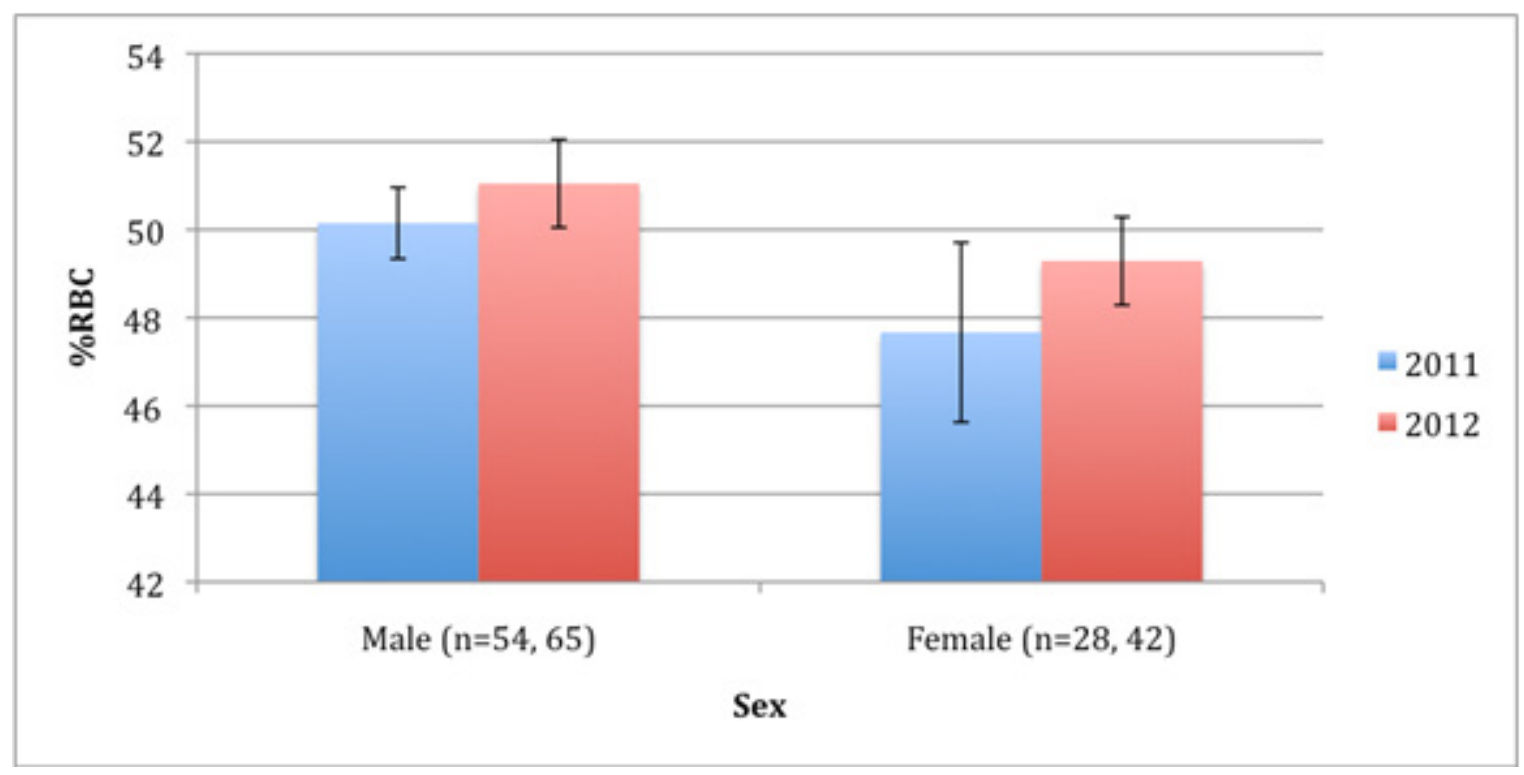

Figure 12. Mean hematocrit (percent red blood cells) of adult male and female Song Sparrows (Melospiza melodia) captured within the upper Santa Cruz River watershed, Arizona, during 2011 and 2012. Error bars represent the 95 percent confidence intervals. Sample sizes are given in parentheses following each sex, with numbers collected from 2011 on left and 2012 on right). 


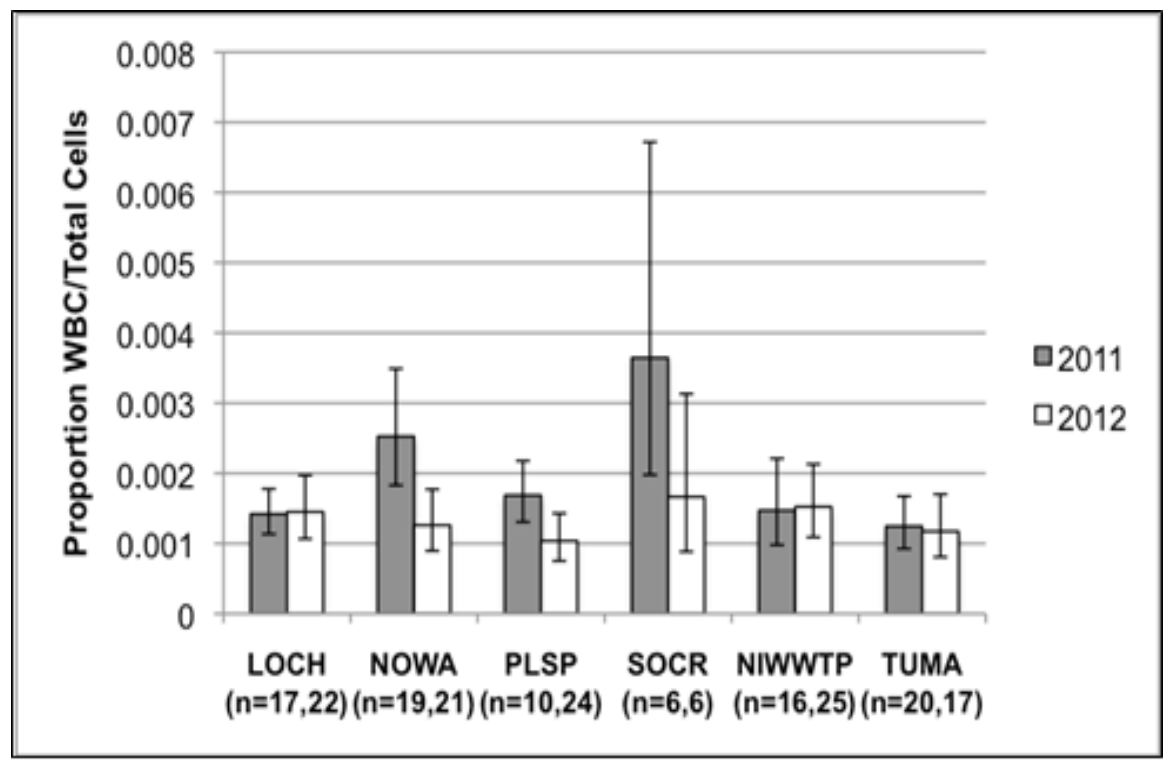

Figure 13. Mean proportion of white blood cells per total number of cells read for Song Sparrows (Melospiza melodia) in 2011 and 2012 at six field sites within the upper Santa Cruz River watershed, southern Arizona. Error bars represent the 95 percent confidence interval. Sample sizes are given in parentheses below each study area, with numbers from 2011 on left and 2012 on right). Study sites: LOCH, Lochiel (San Rafael Grasslands-control site); NOWA, Nogales Wash; PLSP, Sonoita Creek (above Patagonia Lake); SOCR, Sonoita Creek (below Patagonia Lake); NIWWTP, Nogales International Wastewater Treatment Plant; TUMA, Tumacacori National Historical Park.

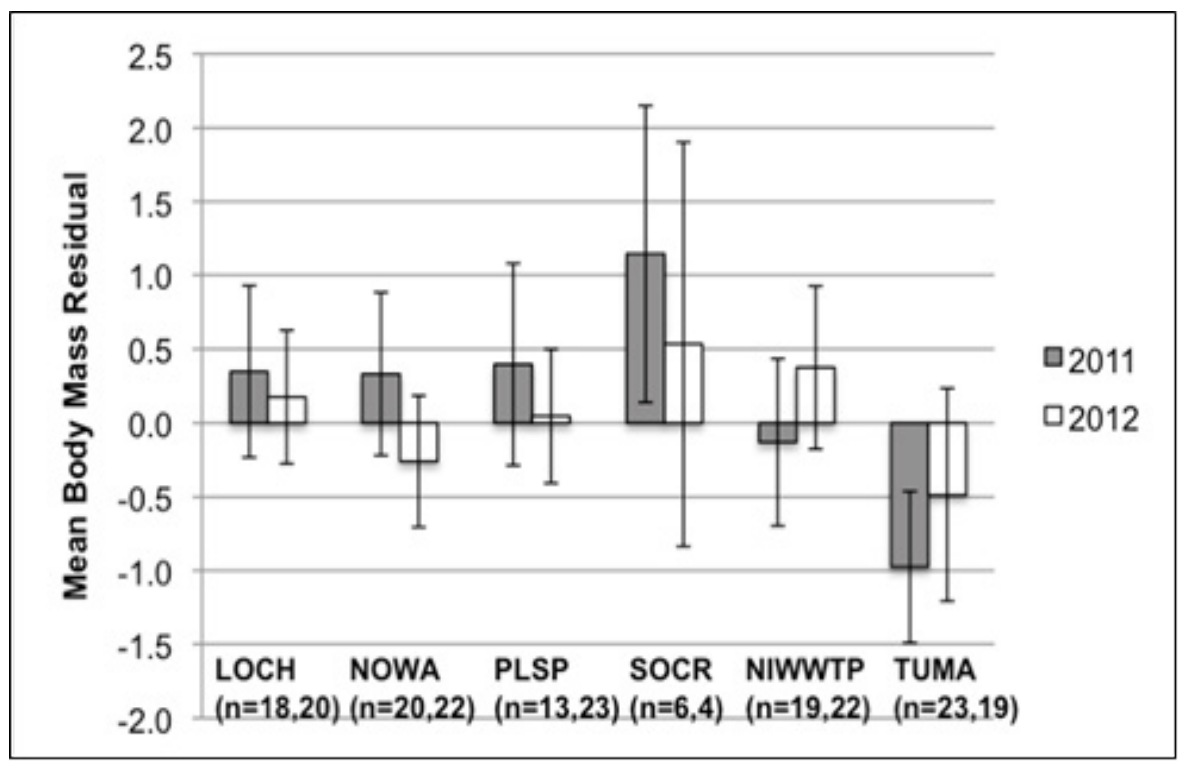

Figure 14. Mean body mass residual score of adult Song Sparrows (Melospiza melodia) in 2011 and 2012 for six sites within the upper Santa Cruz River watershed, southern Arizona. Error bars represent the 95 percent confidence interval. Sample sizes are given in parentheses below each study area, with numbers from 2011 on left and 2012 on right). Study sites: LOCH, Lochiel (San Rafael Grasslands—control site); NOWA, Nogales Wash; PLSP, Sonoita Creek (above Patagonia Lake); SOCR, Sonoita Creek (below Patagonia Lake); NIWWTP, Nogales International Wastewater Treatment Plant; TUMA, Tumacacori National Historical Park. 
Table 1. Mean natural log (Ln) in parts per million and standard error (SE) of 21 heavy metals in tail feathers of adult Song Sparrows at six sites in the upper Santa Cruz River watershed, southern Arizona, 2011.

[Average background concentrations found in literature (Lit.); number of studies that information was taken from is given in parentheses. For information from more than one reference study, those data are presented with a standard error (SE). Sites sharing the same parenthetical letters, for example (A), (B), or (C), do not differ significantly. An asterisk indicates at least one significant difference among sites. Study sites: LOCH, Lochiel (San Rafael Grasslands—control site); NOWA, Nogales Wash; PLSP, Sonoita Creek (above Patagonia Lake); SOCR, Sonoita Creek (below Patagonia Lake); NIWWTP, Nogales International Wastewater Treatment Plant; TUMA, Tumacacori National Historical Park]

\begin{tabular}{|c|c|c|c|c|c|c|c|c|c|c|c|c|c|c|c|c|}
\hline Metal & $\begin{array}{l}\mathrm{LOCH} \\
(\mathrm{n}=19)\end{array}$ & SE & $\begin{array}{l}\text { NIWWTP } \\
(n=18)\end{array}$ & SE & $\begin{array}{l}\text { NOWA } \\
(n=21)\end{array}$ & SE & $\begin{array}{l}\text { PLSP } \\
(n=13)\end{array}$ & SE & $\begin{array}{l}\text { SOCR } \\
(n=5)\end{array}$ & SE & $\begin{array}{l}\text { TUMA } \\
(n=23)\end{array}$ & SE & $\mathbf{F}$ & $p$ & $\begin{array}{l}\text { Lit. } \\
\text { (n) }\end{array}$ & SE \\
\hline $\mathrm{Ag}$ & $-4.758(\mathrm{~A})$ & 0.26 & $-5.086(\mathrm{~A})$ & 0.28 & $-4.884(\mathrm{~A})$ & 0.23 & $-4.852(\mathrm{~A})$ & 0.44 & $-4.936(\mathrm{~A})$ & 0.22 & $-4.840(\mathrm{~A})$ & 0.27 & 0.3779 & 0.8625 & $-2.040(1)$ & - \\
\hline $\mathrm{Al}$ & 5.151(A) & 0.11 & 5.018(A) & 0.09 & 5.069(A) & 0.10 & $4.976(\mathrm{~A})$ & 0.10 & 5.219(A) & 0.13 & $5.087(\mathrm{~A})$ & 0.09 & 1.8299 & 0.1163 & $4.715(5)$ & 0.34 \\
\hline As & $-1.007(\mathrm{~A})$ & 0.12 & $-1.457(\mathrm{C})$ & 0.09 & $-1.298(\mathrm{~B})$ & 0.10 & $-1.052(\mathrm{ABC})$ & 0.11 & $-1.019(\mathrm{AB})$ & 0.19 & $-1.452(\mathrm{C})$ & 0.07 & 5.7764 & $0.0001 *$ & $0.482(4)$ & 0.68 \\
\hline $\mathrm{Ba}$ & $2.446(\mathrm{~A})$ & 0.15 & 2.008(B) & 0.09 & 2.197(B) & 0.13 & $1.446(\mathrm{~B})$ & 0.11 & $2.000(\mathrm{AB})$ & 0.21 & 2.233(B) & 0.08 & 4.4341 & $0.0013^{*}$ & $2.331(2)$ & 0.30 \\
\hline Cd & $-2.586(\mathrm{~A})$ & 0.11 & $-0.789(\mathrm{~B})$ & 0.11 & $-1.463(\mathrm{C})$ & 0.12 & $-1.240(\mathrm{BC})$ & 0.10 & $-2.381(\mathrm{~A})$ & 0.20 & $-0.923(\mathrm{C})$ & 0.09 & 28.2896 & $<0.0001^{*}$ & $-0.671(8)$ & 0.28 \\
\hline $\mathrm{Cr}$ & $-1.430(\mathrm{~A})$ & 0.11 & $-0.996(\mathrm{~B})$ & 0.08 & $-1.143(\mathrm{~B})$ & 0.08 & $-1.724(\mathrm{AB})$ & 0.12 & $-1.364(\mathrm{AB})$ & 0.16 & $-0.949(\mathrm{~B})$ & 0.09 & 2.7657 & $0.0235 *$ & $0.175(4)$ & 0.63 \\
\hline $\mathrm{Cu}$ & $2.463(\mathrm{~A})$ & 0.05 & $2.499(\mathrm{~A})$ & 0.03 & 2.616(B) & 0.05 & $2.477(\mathrm{AB})$ & 0.06 & $2.374(\mathrm{AB})$ & 0.05 & $2.475(\mathrm{~A})$ & 0.03 & 3.1866 & $0.0113^{*}$ & $2.156(9)$ & 0.08 \\
\hline $\mathrm{Fe}$ & $5.670(\mathrm{~A})$ & 0.12 & 5.311(BC) & 0.09 & $5.576(\mathrm{AB})$ & 0.10 & 5.391(ABC) & 0.10 & $5.556(\mathrm{ABC})$ & 0.13 & $5.400(\mathrm{C})$ & 0.09 & 3.8058 & $0.0038 *$ & $4.838(2)$ & 0.42 \\
\hline $\mathrm{Hg}$ & $-1.642(\mathrm{~A})$ & 0.27 & $-1.552(\mathrm{~A})$ & 0.26 & $-1.473(\mathrm{~A})$ & 0.18 & $-1.144(\mathrm{~A})$ & 0.15 & $0.742(\mathrm{~B})$ & 0.62 & $-1.469(\mathrm{~A})$ & 0.17 & 3.0617 & $0.0140 *$ & $-0.068(6)$ & 0.22 \\
\hline $\mathrm{Mg}$ & 5.078(A) & 0.08 & 5.059(A) & 0.05 & $5.080(\mathrm{~A})$ & 0.07 & 5.096(A) & 0.07 & 5.176(A) & 0.23 & 5.138(A) & 0.06 & 1.1787 & 0.3270 & - & - \\
\hline $\mathrm{Mn}$ & 4.076(A) & 0.18 & 3.427(B) & 0.14 & 3.658(B) & 0.18 & 4.243(ABC) & 0.14 & 4.801(C) & 0.31 & 3.786(B) & 0.11 & 5.4383 & $0.0002 *$ & $2.872(6)$ & 0.66 \\
\hline Mo & $-1.154(\mathrm{~A})$ & 0.05 & $-0.830(\mathrm{~B})$ & 0.03 & $-0.864(\mathrm{~B})$ & 0.05 & $-1.794(\mathrm{~A})$ & 0.11 & $-1.367(\mathrm{AB})$ & 0.11 & $-0.889(\mathrm{~B})$ & 0.04 & 4.8374 & $0.0006 *$ & $-1.073(1)$ & - \\
\hline $\mathrm{Ni}$ & $0.029(\mathrm{~A})$ & 0.20 & 1.352(B) & 0.14 & $-0.175(\mathrm{~A})$ & 0.13 & $-0.384(\mathrm{~A})$ & 0.18 & $-0.399(\mathrm{~A})$ & 0.11 & $0.427(\mathrm{~A})$ & 0.12 & 13.4433 & $<0.0001^{*}$ & $-0.358(5)$ & 0.34 \\
\hline $\mathrm{Pb}$ & $-0.350(\mathrm{~A})$ & 0.10 & $-0.038(\mathrm{~B})$ & 0.06 & $0.046(\mathrm{~B})$ & 0.09 & $0.770(\mathrm{ABC})$ & 0.09 & $0.824(\mathrm{C})$ & 0.13 & $0.196(\mathrm{~B})$ & 0.06 & 5.1424 & $0.0004^{*}$ & $1.896(8)$ & 0.34 \\
\hline $\mathrm{Sb}$ & $-3.369(\mathrm{~A})$ & 0.10 & $-2.908(\mathrm{~B})$ & 0.05 & $-2.371(\mathrm{~B})$ & 0.10 & $-2.770(\mathrm{ABC})$ & 0.09 & $-2.518(\mathrm{~B})$ & 0.08 & $-2.971(\mathrm{AB})$ & 0.05 & 19.1914 & $<0.0001^{*}$ & $-2.283(1)$ & - \\
\hline Se & $-0.228(\mathrm{~A})$ & 0.18 & $0.150(\mathrm{~A})$ & 0.14 & $0.201(\mathrm{~A})$ & 0.19 & $-0.575(\mathrm{~A})$ & 0.19 & $0.256(\mathrm{~A})$ & 0.25 & $-0.491(\mathrm{~A})$ & 0.15 & 0.4042 & 0.2317 & $0.412(4)$ & 0.47 \\
\hline $\mathrm{Sr}$ & $2.140(\mathrm{~A})$ & 0.13 & 2.034(A) & 0.10 & 2.002(A) & 0.12 & 2.011(A) & 0.10 & 2.111(A) & 0.20 & 2.391(A) & 0.09 & 0.7161 & 0.6131 & $2.063(2)$ & 0.09 \\
\hline $\mathrm{Tl}$ & $-5.548(\mathrm{~A})$ & 0.09 & $-5.907(\mathrm{~B})$ & 0.07 & $-5.852(\mathrm{~B})$ & 0.08 & $-5.130(\mathrm{AB})$ & 0.10 & $-5.479(\mathrm{~A})$ & 0.11 & $-5.973(\mathrm{~B})$ & 0.09 & 5.9579 & $<0.0001^{*}$ & $-0.978(1)$ & - \\
\hline $\mathrm{U}$ & $-3.770(\mathrm{~A})$ & 0.10 & $-3.187(B)$ & 0.09 & $-2.885(\mathrm{C})$ & 0.08 & $-3.406(\mathrm{AB})$ & 0.09 & $-3.625(\mathrm{ABC})$ & 0.11 & $-3.150(\mathrm{AB})$ & 0.07 & 13.2079 & $<0.0001^{*}$ & - & - \\
\hline V & $-0.784(\mathrm{~A})$ & 0.11 & $-0.799(\mathrm{~A})$ & 0.08 & $-0.762(\mathrm{~A})$ & 0.08 & $-1.061(\mathrm{~A})$ & 0.09 & $-0.868(\mathrm{~A})$ & 0.10 & $-0.621(\mathrm{~A})$ & 0.06 & 1.5775 & 0.7844 & $0.384(1)$ & - \\
\hline Zn & $5.237(\mathrm{~A})$ & 0.03 & $5.282(\mathrm{~A})$ & 0.02 & $5.298(\mathrm{~A})$ & 0.02 & $5.214(\mathrm{~B})$ & 0.06 & $5.297(\mathrm{~A})$ & 0.03 & $5.205(\mathrm{~A})$ & 0.03 & 2.4513 & $0.0405^{*}$ & $5.070(9)$ & 0.10 \\
\hline
\end{tabular}


Table 2. Mean natural log (Ln) in parts per million and standard error (SE) of 21 heavy metals in tail feathers of adult Song Sparrows at six sites in the upper Santa Cruz River watershed, southern Arizona, 2012.

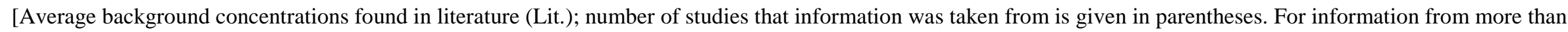

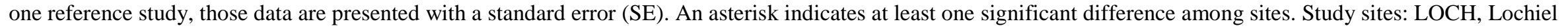

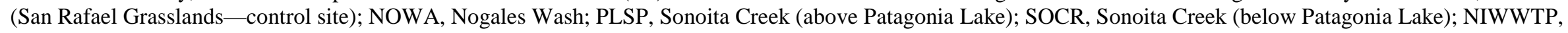
Nogales International Wastewater Treatment Plant; TUMA, Tumacacori National Historical Park]

\begin{tabular}{|c|c|c|c|c|c|c|c|c|c|c|c|c|c|c|c|c|}
\hline Metal & $\begin{array}{l}\mathrm{LOCH} \\
(n=20)\end{array}$ & SE & $\begin{array}{l}\text { NIWWTP } \\
(n=20)\end{array}$ & SE & $\begin{array}{l}\text { NOWA } \\
(n=20)\end{array}$ & SE & $\begin{array}{l}\text { PLSP } \\
(n=20)\end{array}$ & SE & $\begin{array}{c}\text { SOCR } \\
(n=6)\end{array}$ & SE & $\begin{array}{l}\text { TUMA } \\
(n=16)\end{array}$ & SE & $\mathbf{F}$ & $p$ & $\begin{array}{l}\text { Lit. } \\
\text { (n) }\end{array}$ & SE \\
\hline Ag & $-3.254(\mathrm{~A})$ & 0.29 & $-3.451(\mathrm{~A})$ & 0.14 & $-3.645(\mathrm{~A})$ & 0.16 & $-3.699(\mathrm{~A})$ & 0.17 & $-3.135(\mathrm{~A})$ & 0.21 & $-4.611(\mathrm{~A})$ & 0.17 & 1.8273 & 0.1801 & $-2.040(1)$ & - \\
\hline $\mathrm{Al}$ & $5.244(\mathrm{~A})$ & 0.12 & 5.351(A) & 0.09 & 5.393(A) & 0.12 & 5.117(A) & 0.10 & $5.320(\mathrm{~A})$ & 0.09 & 5.028(A) & 0.11 & 1.1781 & 0.3270 & $4.715(5)$ & 0.34 \\
\hline As & $-1.188(\mathrm{AB})$ & 0.13 & $-1.262(\mathrm{BC})$ & 0.08 & $-0.880(\mathrm{~A})$ & 0.12 & $-1.022(\mathrm{AB})$ & 0.09 & $-0.801(\mathrm{ABC})$ & 0.16 & $-1.708(\mathrm{C})$ & 0.09 & 4.2432 & $0.0017^{*}$ & $0.482(4)$ & 0.68 \\
\hline $\mathrm{Ba}$ & 2.818(A) & 0.15 & 2.092(B) & 0.09 & $2.418(\mathrm{C})$ & 0.10 & $1.677(\mathrm{D})$ & 0.13 & 2.072(ABCD) & 0.13 & 2.079(BD) & 0.11 & 19.5213 & $<0.0001^{*}$ & $2.331(2)$ & 0.30 \\
\hline $\mathrm{Cd}$ & $-2.194(\mathrm{~A})$ & 0.13 & $0.001(\mathrm{~B})$ & 0.20 & $-1.129(\mathrm{C})$ & 0.17 & $-0.972(\mathrm{C})$ & 0.08 & $-1.989(\mathrm{ABC})$ & 0.20 & $-1.056(\mathrm{C})$ & 0.13 & 19.6068 & $<0.0001 *$ & $-0.671(8)$ & 0.28 \\
\hline $\mathrm{Cr}$ & $-1.215(\mathrm{~A})$ & 0.22 & $-0.687(\mathrm{~B})$ & 0.22 & $-0.841(\mathrm{AB})$ & 0.14 & $-1.678(\mathrm{C})$ & 0.16 & $-0.998(\mathrm{ABC})$ & 0.33 & $-1.364(\mathrm{AB})$ & 0.12 & 4.1930 & $0.0019 *$ & $0.175(4)$ & 0.63 \\
\hline $\mathrm{Cu}$ & $2.305(\mathrm{~A})$ & 0.11 & $2.404(\mathrm{~A})$ & 0.06 & $2.720(\mathrm{~B})$ & 0.10 & $2.376(\mathrm{~A})$ & 0.04 & $2.351(\mathrm{AB})$ & 0.12 & $2.146(\mathrm{~A})$ & 0.07 & 2.9834 & $0.0159 *$ & $2.156(9)$ & 0.08 \\
\hline $\mathrm{Fe}$ & $5.514(\mathrm{AB})$ & 0.14 & $5.514(\mathrm{AB})$ & 0.09 & $5.781(\mathrm{~A})$ & 0.14 & 5.337(B) & 0.11 & $5.531(\mathrm{AB})$ & 0.08 & 5.139(B) & 0.10 & 2.9353 & $0.0173^{*}$ & $4.838(2)$ & 0.42 \\
\hline $\mathrm{Hg}$ & $-2.708(\mathrm{~A})$ & 0.17 & $-1.664(\mathrm{BC})$ & 0.14 & $-1.328(\mathrm{C})$ & 0.25 & $-1.957(\mathrm{BC})$ & 0.22 & $0.050(\mathrm{D})$ & 1.57 & $-2.681(\mathrm{AB})$ & 0.15 & 5.9185 & $<0.0001 *$ & $-0.068(6)$ & 0.22 \\
\hline $\mathrm{Mg}$ & 5.375(A) & 0.11 & $5.361(\mathrm{~A})$ & 0.06 & $5.580(\mathrm{~A})$ & 0.08 & $5.437(\mathrm{~A})$ & 0.07 & $5.486(\mathrm{~A})$ & 0.11 & $5.171(\mathrm{~A})$ & 0.06 & 1.7051 & 0.1425 & - & - \\
\hline $\mathrm{Mn}$ & $4.334(\mathrm{~A})$ & 0.17 & 3.565(B) & 0.12 & $3.921(\mathrm{C})$ & 0.13 & $4.662(\mathrm{~A})$ & 0.12 & $4.475(\mathrm{ABC})$ & 0.30 & 3.579(B) & 0.13 & 13.6671 & $<0.0001^{*}$ & $2.872(6)$ & 0.66 \\
\hline Mo & $-1.379(\mathrm{~A})$ & 0.10 & $-0.938(B)$ & 0.09 & $-0.575(\mathrm{C})$ & 0.09 & $-1.628(\mathrm{~A})$ & 0.12 & $-1.386(\mathrm{ABC})$ & 0.11 & $-1.095(\mathrm{~B})$ & 0.08 & 14.0622 & $<0.0001 *$ & $-1.073(1)$ & - \\
\hline $\mathrm{Ni}$ & $-0.388(\mathrm{AC})$ & 0.14 & $0.722(\mathrm{~B})$ & 0.11 & $-0.029(\mathrm{C})$ & 0.15 & $-0.480(\mathrm{~A})$ & 0.06 & $-0.283(\mathrm{ABC})$ & 0.11 & $-0.640(\mathrm{~A})$ & 0.10 & 15.5751 & $<0.0001^{*}$ & $-0.358(5)$ & 0.34 \\
\hline $\mathrm{Pb}$ & $-0.593(\mathrm{~A})$ & 0.12 & $0.031(\mathrm{BC})$ & 0.10 & $0.100(\mathrm{~B})$ & 0.12 & $0.778(\mathrm{D})$ & 0.07 & $0.750(\mathrm{ABCD})$ & 0.14 & $-0.356(\mathrm{AC})$ & 0.07 & 18.7977 & $<0.0001^{*}$ & $1.896(8)$ & 0.34 \\
\hline $\mathrm{Sb}$ & $-3.485(\mathrm{~A})$ & 0.16 & $-2.663(\mathrm{~B})$ & 0.09 & $-2.250(\mathrm{C})$ & 0.12 & $-2.719(\mathrm{~B})$ & 0.09 & $-2.600(\mathrm{ABC})$ & 0.12 & $-3.249(\mathrm{~A})$ & 0.07 & 11.8235 & $<0.0001 *$ & $-2.283(1)$ & - \\
\hline Se & $-0.390(\mathrm{~A})$ & 0.26 & $0.296(\mathrm{AB})$ & 0.07 & $0.650(\mathrm{~B})$ & 0.12 & $-0.100(\mathrm{~A})$ & 0.11 & $0.045(\mathrm{ABC})$ & 0.15 & $-1.740(\mathrm{C})$ & 0.45 & 5.9181 & $<0.0001 *$ & $0.412(4)$ & 0.47 \\
\hline $\mathrm{Sr}$ & $2.659(\mathrm{~A})$ & 0.14 & 2.112(B) & 0.09 & $2.377(\mathrm{C})$ & 0.10 & $2.481(\mathrm{C})$ & 0.11 & $2.419(\mathrm{ABC})$ & 0.20 & $2.256(\mathrm{BC})$ & 0.10 & 6.0776 & $<0.0001^{*}$ & $2.063(2)$ & 0.09 \\
\hline $\mathrm{Tl}$ & $-5.616(\mathrm{~A})$ & 0.12 & $-5.793(\mathrm{~B})$ & 0.07 & $-5.584(\mathrm{AB})$ & 0.10 & $-5.084(C)$ & 0.08 & $-5.384(\mathrm{ABC})$ & 0.10 & $-6.030(\mathrm{AB})$ & 0.09 & 8.5320 & $<0.0001^{*}$ & $-0.978(1)$ & - \\
\hline $\mathrm{U}$ & $-3.672(\mathrm{~A})$ & 0.13 & $-3.133(\mathrm{~B})$ & 0.09 & $-2.725(C)$ & 0.10 & $-3.326(\mathrm{AB})$ & 0.11 & $-3.575(\mathrm{ABC})$ & 0.08 & $-3.315(\mathrm{AB})$ & 0.10 & 9.2162 & $<0.0001^{*}$ & - & - \\
\hline V & $-0.845(\mathrm{~A})$ & 0.14 & $-0.636(\mathrm{~A})$ & 0.09 & $-0.572(\mathrm{~A})$ & 0.10 & $-0.912(\mathrm{~A})$ & 0.11 & $-0.852(\mathrm{~A})$ & 0.07 & $-0.824(\mathrm{~A})$ & 0.09 & 1.9850 & 0.0893 & $0.384(1)$ & - \\
\hline Zn & $5.205(\mathrm{~A})$ & 0.10 & 5.334(A) & 0.06 & $5.413(\mathrm{~A})$ & 0.05 & $5.300(\mathrm{~A})$ & 0.03 & 5.179(A) & 0.07 & $5.008(\mathrm{~A})$ & 0.06 & 1.2722 & 0.2837 & $5.070(9)$ & 0.10 \\
\hline
\end{tabular}


Table 3. Mean difference in natural log-transformed (Ln) heavy metal concentrations between 2011 and 2012 for feathers of 37 Song Sparrows (Melospiza melodia) captured during both years of our study in the upper Santa Cruz River watershed, southern Arizona.

[Only significant metals from a matched-pairs t-test are reported along with standard error, t-ratio (df), and p-value]

\begin{tabular}{ccccc}
\hline Metal & Mean Dif. [Ln(2012)- $\operatorname{Ln}(\mathbf{2 0 1 1})]$ & $\mathbf{S E}$ & $\mathbf{t}($ (36) & $\mathbf{p}$ \\
\hline $\mathrm{Ag}$ & 1.6630 & 0.2289 & 7.26 & $<0.0001$ \\
$\mathrm{Al}$ & 0.2493 & 0.0829 & 3.01 & 0.0024 \\
$\mathrm{Cd}$ & 0.3201 & 0.1116 & 2.87 & 0.0034 \\
$\mathrm{Cr}$ & 0.2019 & 0.1152 & 1.75 & 0.0441 \\
$\mathrm{Mg}$ & 0.2971 & 0.0678 & 4.38 & $<0.0001$ \\
$\mathrm{Sr}$ & 0.1774 & 0.0956 & 1.86 & 0.0358 \\
$\mathrm{Tl}$ & 0.1515 & 0.0737 & 2.06 & 0.0235 \\
\hline
\end{tabular}

Table 4. Mean difference in natural log-transformed (Ln) heavy metal concentrations between 2011 and 2012 for feathers of all adult Song Sparrows (Melospiza melodia) captured in the upper Santa Cruz River watershed, southern Arizona.

[Only significant metals from a Student's t-test are reported along with standard error (SE), t-ratio (df), and p-value. 2011 $\mathrm{n}=$ 99; $2012 \mathrm{n}=102]$

\begin{tabular}{ccccc}
\hline Metal & Mean Dif. [Ln(2012)- $\mathbf{L n}(\mathbf{2 0 1 1})]$ & $\mathrm{SE}$ & $\mathbf{t}_{(199)}$ & $\mathbf{p}$ \\
\hline $\mathrm{Ag}$ & 1.2259 & 0.1510 & 8.12 & $<0.0001$ \\
$\mathrm{Al}$ & 0.1618 & 0.0633 & 2.56 & 0.0057 \\
$\mathrm{Cd}$ & 0.3146 & 0.1254 & 2.51 & 0.0065 \\
$\mathrm{Cu}$ & -0.1053 & 0.0431 & -2.44 & 0.0079 \\
$\mathrm{Hg}$ & -55.4800 & 0.1538 & -3.61 & 0.0002 \\
$\mathrm{Mg}$ & 0.3028 & 0.0458 & 6.61 & $<0.0001$ \\
$\mathrm{Mn}$ & 0.2007 & 0.1028 & 1.95 & 0.0262 \\
$\mathrm{Ni}$ & -0.4102 & 0.1111 & -3.69 & 0.0001 \\
$\mathrm{Sr}$ & 0.2521 & 0.0707 & 3.57 & 0.0002 \\
$\mathrm{Tl}$ & 0.1267 & 0.0678 & 1.87 & 0.0316 \\
\hline
\end{tabular}


Table 5. Mean natural log (Ln) in parts per million and standard error of 21 elements in blood of adult Song Sparrows at six sites in the upper Santa Cruz River watershed, Arizona, 2011.

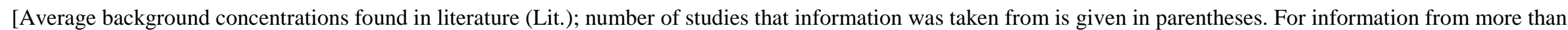

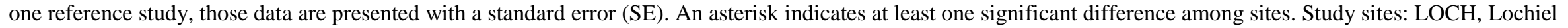

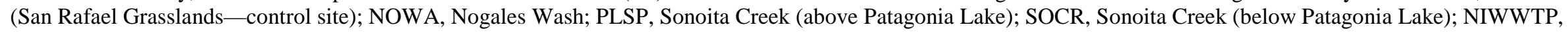
Nogales International Wastewater Treatment Plant; TUMA, Tumacacori National Historical Park]

\begin{tabular}{|c|c|c|c|c|c|c|c|c|c|c|c|c|c|c|c|c|}
\hline Metal & $\begin{array}{l}\mathrm{LOCH} \\
(n=18)\end{array}$ & SE & $\begin{array}{l}\text { NIWWTP } \\
(n=16)\end{array}$ & SE & $\begin{array}{l}\text { NOWA } \\
(n=20)\end{array}$ & SE & $\begin{array}{l}\text { PLSP } \\
(n=13)\end{array}$ & SE & $\begin{array}{l}\text { SOCR } \\
(n=6)\end{array}$ & SE & $\begin{array}{l}\text { TUMA } \\
(n=21)\end{array}$ & SE & $\mathbf{F}$ & $p$ & Lit. (n) & SE \\
\hline Ag & $-7.851(\mathrm{~A})$ & 0.41 & $-7.350(\mathrm{~A})$ & 0.41 & $-7.538(\mathrm{~A})$ & 0.40 & $-8.047(\mathrm{~A})$ & 0.35 & $-7.385(\mathrm{~A})$ & 0.72 & $-7.497(\mathrm{~A})$ & 0.41 & 0.1134 & 0.9891 & - & - \\
\hline $\mathrm{Al}$ & $0.684(\mathrm{~A})$ & 0.27 & $0.512(\mathrm{~A})$ & 0.22 & $0.743(\mathrm{~A})$ & 0.21 & $0.076(\mathrm{~A})$ & 0.10 & $1.151(\mathrm{~A})$ & 0.61 & $0.541(\mathrm{~A})$ & 0.16 & 0.9100 & 0.4788 & $4.404(2)$ & 0.04 \\
\hline As & $-3.836(\mathrm{~A})$ & 0.31 & $-4.617(\mathrm{AB})$ & 0.33 & $-3.588(\mathrm{~A})$ & 0.25 & $-4.388(\mathrm{AB})$ & 0.31 & $-3.833(\mathrm{~A})$ & 0.10 & $-5.017(\mathrm{~B})$ & 0.27 & 3.0599 & 0.0139* & $-2.07(4)$ & 0.95 \\
\hline $\mathrm{Ba}$ & $-2.982(\mathrm{~A})$ & 0.22 & $-3.130(\mathrm{~A})$ & 0.15 & $-3.037(\mathrm{~A})$ & 0.24 & $-3.590(\mathrm{~A})$ & 0.16 & $-2.945(\mathrm{~A})$ & 0.34 & $-3.006(\mathrm{~A})$ & 0.14 & 0.3123 & 0.9043 & $-0.051(1)$ & - \\
\hline $\mathrm{Cd}$ & $-5.915(\mathrm{~A})$ & 0.12 & $-5.448(B)$ & 0.10 & $-5.338(B)$ & 0.13 & $-5.445(\mathrm{~B})$ & 0.12 & $-6.154(\mathrm{~A})$ & 0.10 & $-5.439(B)$ & 0.10 & 4.2635 & $0.0017^{*}$ & $-3.732(6)$ & 0.85 \\
\hline $\mathrm{Cr}$ & $-4.037(\mathrm{~A})$ & 0.24 & $-4.115(\mathrm{~A})$ & 0.29 & $-4.119(\mathrm{~A})$ & 0.28 & $-4.420(\mathrm{~A})$ & 0.26 & $-3.468(\mathrm{~A})$ & 0.33 & $-4.110(\mathrm{~A})$ & 0.14 & 0.5452 & 0.7415 & $1.719(4)$ & 0.76 \\
\hline $\mathrm{Cu}$ & $-0.347(\mathrm{~A})$ & 0.10 & $-0.158(\mathrm{~A})$ & 0.10 & $-0.090(\mathrm{~A})$ & 0.12 & $-0.132(\mathrm{~A})$ & 0.28 & $-0.499(\mathrm{~A})$ & 0.07 & $-0.129(\mathrm{~A})$ & 0.09 & 0.5899 & 0.7077 & $-0.074(6)$ & 0.59 \\
\hline $\mathrm{Fe}$ & $6.913(\mathrm{~A})$ & 0.09 & $7.077(\mathrm{~A})$ & 0.12 & $7.000(\mathrm{~A})$ & 0.11 & $6.794(\mathrm{~A})$ & 0.08 & $6.674(\mathrm{~A})$ & 0.08 & 6.992(A) & 0.11 & 0.8126 & 0.5440 & $5.866(6)$ & 0.92 \\
\hline $\mathrm{Hg}$ & $-2.971(\mathrm{~A})$ & 0.24 & $-3.068(\mathrm{~A})$ & 0.19 & $-2.536(\mathrm{~A})$ & 0.21 & $-2.979(\mathrm{~A})$ & 0.14 & $-2.595(\mathrm{~A})$ & 0.09 & $-2.626(\mathrm{~A})$ & 0.19 & 0.6325 & 0.6755 & $-2.049(7)$ & 0.44 \\
\hline $\mathrm{Mg}$ & $5.264(\mathrm{~A})$ & 0.08 & 5.387(A) & 0.11 & $5.404(\mathrm{~A})$ & 0.13 & 5.127(A) & 0.07 & $5.074(\mathrm{~A})$ & 0.04 & $5.310(\mathrm{~A})$ & 0.09 & 0.6978 & 0.6266 & 5.150 (3) & 0.57 \\
\hline $\mathrm{Mn}$ & $-1.644(\mathrm{~A})$ & 0.27 & $-1.822(\mathrm{~A})$ & 0.18 & $-1.880(\mathrm{~A})$ & 0.19 & $-1.825(\mathrm{~A})$ & 0.14 & $-1.174(\mathrm{~A})$ & 0.22 & $-1.828(\mathrm{~A})$ & 0.11 & 0.9708 & 0.4407 & $-0.856(5)$ & 0.81 \\
\hline Mo & $-2.625(\mathrm{~A})$ & 0.10 & $-2.390(\mathrm{~A})$ & 0.16 & $-2.643(\mathrm{~A})$ & 0.12 & $-3.178(\mathrm{~A})$ & 0.11 & $-2.970(\mathrm{~A})$ & 0.07 & $-2.619(\mathrm{~A})$ & 0.12 & 1.7037 & 0.1430 & $-3.650(1)$ & - \\
\hline $\mathrm{Ni}$ & $-5.472(\mathrm{~A})$ & 0.25 & $-4.595(\mathrm{~A})$ & 0.46 & $-5.215(\mathrm{~A})$ & 0.30 & $-4.692(\mathrm{~A})$ & 0.55 & $-4.828(\mathrm{~A})$ & 0.74 & $-4.909(\mathrm{~A})$ & 0.34 & 0.9117 & 0.4777 & $1.155(2)$ & 1.23 \\
\hline $\mathrm{Pb}$ & $-3.521(\mathrm{~A})$ & 0.20 & $-3.337(\mathrm{~A})$ & 0.12 & $-3.461(\mathrm{~A})$ & 0.13 & $-3.232(\mathrm{~A})$ & 0.08 & $-3.462(\mathrm{~A})$ & 0.21 & $-3.339(\mathrm{~A})$ & 0.10 & 0.3249 & 0.8966 & $-1.392(4)$ & .125 \\
\hline $\mathrm{Sb}$ & $-6.624(\mathrm{~A})$ & 0.35 & $-6.429(\mathrm{~A})$ & 0.22 & $-5.858(\mathrm{~A})$ & 0.34 & $-6.489(\mathrm{~A})$ & 0.24 & $-6.427(\mathrm{~A})$ & 0.27 & $-6.450(\mathrm{~A})$ & 0.31 & 0.9898 & 0.4292 & - & - \\
\hline Se & $0.918(\mathrm{~A})$ & 0.11 & $1.215(\mathrm{~A})$ & 0.13 & $2.277(\mathrm{~B})$ & 0.21 & $0.712(\mathrm{~A})$ & 0.15 & 1.809(B) & 0.18 & 1.166(A) & 0.16 & 12.1130 & $<0.0001^{*}$ & $0.587(5)$ & 0.52 \\
\hline $\mathrm{Sr}$ & $-2.159(\mathrm{~A})$ & 0.15 & $-2.550(\mathrm{~A})$ & 0.15 & $-2.270(\mathrm{~A})$ & 0.21 & $-2.088(\mathrm{~A})$ & 0.17 & $-1.975(\mathrm{~A})$ & 0.36 & $-2.240(\mathrm{~A})$ & 0.12 & 1.8067 & 0.1206 & $-0.276(2)$ & 0.54 \\
\hline $\mathrm{Tl}$ & $-8.492(\mathrm{AB})$ & 0.18 & $-8.808(C)$ & 0.21 & $-8.064(\mathrm{CD})$ & 0.13 & $-7.683(\mathrm{D})$ & 0.10 & $-8.113(\mathrm{CD})$ & 0.15 & $-8.738(\mathrm{BC})$ & 0.11 & 6.6907 & $<0.0001^{*}$ & - & - \\
\hline $\mathrm{U}$ & $-8.590(\mathrm{~A})$ & 0.27 & $-8.158(\mathrm{~A})$ & 0.21 & $-7.998(\mathrm{~A})$ & 0.22 & $-8.350(\mathrm{~A})$ & 0.12 & $-8.526(\mathrm{~A})$ & 0.19 & $-8.066(\mathrm{~A})$ & 0.13 & 1.1049 & 0.3643 & - & - \\
\hline $\mathrm{V}$ & $-5.489(\mathrm{AB})$ & 0.30 & $-4.949(\mathrm{BC})$ & 0.17 & $-4.747(\mathrm{C})$ & 0.17 & $-6.050(\mathrm{~A})$ & 0.07 & $-5.466(\mathrm{ABC})$ & 0.23 & $-5.041(\mathrm{BC})$ & 0.11 & 3.4742 & $0.0067^{*}$ & $-1.645(1)$ & - \\
\hline $\mathrm{Zn}$ & $2.092(\mathrm{~A})$ & 0.10 & $2.233(\mathrm{~A})$ & 0.12 & $2.311(\mathrm{~A})$ & 0.13 & 1.991(A) & 0.11 & $2.031(\mathrm{~A})$ & 0.07 & $2.254(\mathrm{~A})$ & 0.10 & 0.4937 & 0.7801 & $2.182(6)$ & 0.44 \\
\hline
\end{tabular}


Table 6. Mean Ln (PPM) and standard error of 21 elements found in blood of adult Song Sparrows at six sites within the upper Santa Cruz River watershed, Arizona, 2012.

[Average background concentrations found in literature (Lit.); number of studies that information was taken from is given in parentheses. For information from more than one reference study, those data are presented with a standard error (SE). An asterisk $\left(^{*}\right)$ indicates at least one significant difference among sites. Study sites: LOCH,

Lochiel (San Rafael Grasslands—control site); NOWA, Nogales Wash; PLSP, Sonoita Creek (above Patagonia Lake); SOCR, Sonoita Creek (below Patagonia Lake); NIWWTP, Nogales International Wastewater Treatment Plant; TUMA, Tumacacori National Historical Park]

\begin{tabular}{|c|c|c|c|c|c|c|c|c|c|c|c|c|c|c|c|c|}
\hline Metal & $\begin{array}{l}\mathrm{LOCH} \\
(n=22)\end{array}$ & SE & $\begin{array}{c}\text { NIWWTP } \\
(n=24)\end{array}$ & SE & $\begin{array}{l}\text { NOWA } \\
(n=21)\end{array}$ & SE & $\begin{array}{l}\text { PLSP } \\
(n=23)\end{array}$ & SE & $\begin{array}{l}\text { SOCR } \\
(n=6)\end{array}$ & SE & $\begin{array}{l}\begin{array}{l}\text { TUMA } \\
(n=17)\end{array} \\
\end{array}$ & SE & $\mathbf{F}$ & $p$ & $\begin{array}{l}\text { Lit. } \\
\text { (n) } \\
\end{array}$ & SE \\
\hline $\mathrm{Ag}$ & $-7.112(\mathrm{~A})$ & 0.26 & $-7.171(\mathrm{~A})$ & 0.26 & $-6.910(\mathrm{~A})$ & 0.20 & $-7.511(\mathrm{~A})$ & 0.36 & $-6.422(\mathrm{~A})$ & 1.26 & $-8.130(\mathrm{~A})$ & 0.34 & 1.325 & 0.2487 & - & - \\
\hline $\mathrm{Al}$ & $0.107(\mathrm{~A})$ & 0.16 & $-0.105(\mathrm{~A})$ & 0.17 & $0.490(\mathrm{~A})$ & 0.17 & $-0.126(\mathrm{~A})$ & 0.14 & $0.309(\mathrm{~A})$ & 0.42 & $-0.065(\mathrm{~A})$ & 0.11 & 1.9615 & 0.0908 & $4.404(2)$ & 0.04 \\
\hline As & $-3.988(\mathrm{~A})$ & 0.12 & $-5.078(\mathrm{BC})$ & 0.17 & $-4.698(\mathrm{CD})$ & 0.12 & $-4.642(\mathrm{DE})$ & 0.15 & $-4.055(\mathrm{AD})$ & 0.31 & $-5.328(\mathrm{C})$ & 0.13 & 11.1916 & $<0.0001^{*}$ & $-2.07(4)$ & 0.95 \\
\hline $\mathrm{Ba}$ & $-2.484(\mathrm{~A})$ & 0.33 & $-3.494(B)$ & 0.22 & $-2.428(\mathrm{~A})$ & 0.30 & $-3.481(\mathrm{~B})$ & 0.28 & $-2.599(\mathrm{AB})$ & 0.51 & $-3.510(\mathrm{~B})$ & 0.21 & 3.0481 & $0.0133 *$ & $-0.051(1)$ & - \\
\hline Cd & $-6.296(\mathrm{~A})$ & 0.08 & $-5.668(\mathrm{BC})$ & 0.12 & $-5.623(\mathrm{C})$ & 0.09 & $-5.775(\mathrm{BC})$ & 0.10 & $-6.373(\mathrm{~A})$ & 0.16 & $-6.062(\mathrm{AB})$ & 0.08 & 7.6857 & $<0.0001^{*}$ & $-3.732(6)$ & 0.85 \\
\hline $\mathrm{Cr}^{\mathrm{b}}$ & $-4.140(\mathrm{~A})$ & 0.28 & $-4.384(\mathrm{~A})$ & 0.37 & $-3.802(\mathrm{~A})$ & 0.34 & $-5.026(\mathrm{~A})$ & 0.31 & $-2.688(\mathrm{~A})$ & 1.39 & $-4.777(\mathrm{~A})$ & 0.27 & 1.5516 & 0.1808 & $1.719(4)$ & 0.76 \\
\hline $\mathrm{Cu}$ & $-0.568(\mathrm{~A})$ & 0.06 & $-0.679(\mathrm{~A})$ & 0.09 & $-0.600(\mathrm{~A})$ & 0.07 & $-0.745(\mathrm{~A})$ & 0.05 & $-0.648(\mathrm{~A})$ & 0.12 & $-0.718(\mathrm{~A})$ & 0.04 & 0.7153 & 0.6134 & $-0.074(6)$ & 0.59 \\
\hline $\mathrm{Fe}$ & 6.469(A) & 0.05 & 6.366(A) & 0.09 & 6.498(A) & 0.03 & 6.411(A) & 0.03 & 6.379(A) & 0.04 & 6.421(A) & 0.02 & 0.8236 & 0.5357 & 5.866 (6) & 0.92 \\
\hline $\mathrm{Hg}$ & $-3.559(\mathrm{AB})$ & 0.10 & $-4.066(\mathrm{C})$ & 0.11 & $-3.116(\mathrm{DE})$ & 0.09 & $-3.466(\mathrm{AD})$ & 0.15 & $-2.773(\mathrm{E})$ & 0.20 & $-4.061(\mathrm{BC})$ & 0.19 & 8.9835 & $<0.0001^{*}$ & $-2.049(7)$ & 0.44 \\
\hline Mg & 4.529(A) & 0.05 & 4.450(A) & 0.09 & 4.633(A) & 0.03 & 4.609(A) & 0.05 & 4.471(A) & 0.06 & 4.636(A) & 0.04 & 1.4094 & 0.2273 & 5.150 (3) & 0.57 \\
\hline Mn & $-2.389(\mathrm{AB})$ & 0.15 & $-2.697(\mathrm{~B})$ & 0.15 & $-2.158(\mathrm{~A})$ & 0.16 & $-2.258(\mathrm{~A})$ & 0.13 & $-1.977(\mathrm{~A})$ & 0.17 & $-2.861(\mathrm{~B})$ & 0.14 & 3.0072 & $0.0143^{*}$ & $-0.856(5)$ & 0.81 \\
\hline Mo & $-2.774(\mathrm{~A})$ & 0.07 & $-3.151(\mathrm{~B})$ & 0.10 & $-3.020(\mathrm{AB})$ & 0.03 & $-3.159(\mathrm{~B})$ & 0.12 & $-2.661(\mathrm{~A})$ & 0.42 & $-3.113(\mathrm{~B})$ & 0.04 & 2.9741 & $0.0151 *$ & $-3.650(1)$ & - \\
\hline $\mathrm{Ni}$ & $-3.763(\mathrm{~A})$ & 0.28 & $-3.636(\mathrm{~A})$ & 0.28 & $-3.544(\mathrm{~A})$ & 0.20 & $-4.125(\mathrm{~A})$ & 0.16 & $-3.874(\mathrm{~A})$ & 0.49 & $-4.302(\mathrm{~A})$ & 0.22 & 0.9218 & 0.4701 & $1.155(2)$ & 1.23 \\
\hline $\mathrm{Pb}$ & $-4.100(\mathrm{~A})$ & 0.19 & $-3.795(\mathrm{AB})$ & 0.28 & $-4.030(\mathrm{~A})$ & 0.17 & $-3.461(\mathrm{~B})$ & 0.12 & $-3.692(\mathrm{AB})$ & 0.10 & $-4.472(\mathrm{~A})$ & 0.06 & 2.3878 & $0.0432 *$ & $-1.392(4)$ & 1.25 \\
\hline $\mathrm{Sb}$ & $-6.395(\mathrm{~A})$ & 0.18 & $-6.049(\mathrm{~A})$ & 0.31 & $-6.198(\mathrm{~A})$ & 0.13 & $-6.665(\mathrm{~A})$ & 0.16 & $-5.747(\mathrm{~A})$ & 0.72 & $-6.771(\mathrm{~A})$ & 0.16 & 1.7319 & 0.1341 & - & - \\
\hline Se & $0.726(\mathrm{~A})$ & 0.10 & $0.772(\mathrm{~A})$ & 0.12 & 2.701(B) & 0.08 & 0.833(A) & 0.15 & 1.595(C) & 0.07 & $0.834(\mathrm{~A})$ & 0.13 & 40.4089 & $<0.0001^{*}$ & 0.587 (5) & 0.52 \\
\hline $\mathrm{Sr}$ & $-2.248(\mathrm{~A})$ & 0.10 & $-3.107(\mathrm{~B})$ & 0.15 & $-2.738(\mathrm{BC})$ & 0.10 & $-2.495(\mathrm{AC})$ & 0.11 & $-2.350(\mathrm{AC})$ & 0.20 & $-2.845(\mathrm{~B})$ & 0.11 & 6.9074 & $<0.0001^{*}$ & $-0.276(2)$ & 0.54 \\
\hline $\mathrm{Tl}$ & $-8.649(\mathrm{~A})$ & 0.10 & $-9.659(B)$ & 0.08 & $-8.733(\mathrm{~A})$ & 0.10 & $-7.853(\mathrm{C})$ & 0.11 & $-8.378(\mathrm{~A})$ & 0.13 & $-9.242(\mathrm{D})$ & 0.12 & 42.4231 & $<0.0001^{*}$ & - & - \\
\hline $\mathrm{U}$ & $-8.643(\mathrm{~A})$ & 0.13 & $-8.539(\mathrm{~A})$ & 0.21 & $-7.720(\mathrm{~B})$ & 0.17 & $-8.529(\mathrm{~A})$ & 0.18 & $-8.643(\mathrm{~A})$ & 0.25 & $-8.617(\mathrm{~A})$ & 0.14 & 4.2286 & $0.0016^{*}$ & - & - \\
\hline $\mathrm{V}$ & $-5.800(\mathrm{~A})$ & 0.19 & $-5.550(\mathrm{~A})$ & 0.15 & $-4.977(\mathrm{~B})$ & 0.14 & $-6.409(\mathrm{C})$ & 0.21 & $-5.365(\mathrm{AB})$ & 0.68 & $-5.528(\mathrm{AB})$ & 0.09 & 6.6289 & $<0.0001^{*}$ & -1.645 (1) & - \\
\hline $\mathrm{Zn}$ & $1.672(\mathrm{~A})$ & 0.09 & $1.549(\mathrm{~A})$ & 0.17 & $1.906(\mathrm{~A})$ & 0.08 & $1.670(\mathrm{~A})$ & 0.06 & 1.734(A) & 0.14 & $1.698(\mathrm{~A})$ & 0.06 & 0.8824 & 0.4958 & $2.182(6)$ & 0.44 \\
\hline
\end{tabular}

b. For Cr, only five adults were analyzed at site SOCR as one adult male showed an extremely high concentration that is likely attributable to a contamination during the sampling process. 
Table 7. Mean difference in log-transformed (Ln) heavy metal concentrations between 2011 and 2012 for blood samples of 33 Song Sparrows (Melospiza melodia) that were captured in both years of our study in the upper Santa Cruz River watershed, southern Arizona.

[Only significant heavy metals from a matched-pairs t-test are reported along with standard error (SE), t-ratio $\mathrm{t}_{(32)}$, and p-value (p)]

\begin{tabular}{ccccc}
\hline Metal & Mean Dif. [Ln(2012)- $\mathbf{L n}(\mathbf{2 0 1 1})]$ & $\mathbf{S E}$ & $\mathbf{t}_{(32)}$ & $\mathbf{p}$ \\
\hline $\mathrm{Al}$ & 0.5869 & 0.1729 & 3.39 & 0.0009 \\
$\mathrm{As}$ & 0.9101 & 0.2305 & 3.95 & 0.0002 \\
$\mathrm{Cd}$ & 0.3707 & 0.0813 & 4.56 & $<0.0001$ \\
$\mathrm{Cu}$ & 0.5355 & 0.1214 & 4.41 & $<0.0001$ \\
$\mathrm{Fe}$ & 0.5126 & 0.0845 & 6.07 & $<0.0001$ \\
$\mathrm{Hg}$ & 0.8785 & 0.1642 & 5.35 & $<0.0001$ \\
$\mathrm{Mg}$ & 0.7762 & 0.0848 & 9.15 & $<0.0001$ \\
$\mathrm{Mn}$ & 0.6760 & 0.1920 & 3.52 & 0.0007 \\
$\mathrm{Mo}$ & 0.3118 & 0.1325 & 2.35 & 0.0125 \\
$\mathrm{Ni}$ & -1.3706 & 0.2687 & -5.10 & $<0.0001$ \\
$\mathrm{~Pb}$ & 0.3667 & 0.1886 & 1.94 & 0.0304 \\
$\mathrm{Sr}$ & 0.5167 & 0.1295 & 3.99 & 0.0002 \\
$\mathrm{Tl}$ & 0.5255 & 0.1288 & 4.08 & 0.0001 \\
$\mathrm{~V}$ & 0.4531 & 0.2135 & 2.12 & 0.0208 \\
$\mathrm{Zn}$ & 0.5715 & 0.0970 & 5.89 & $<0.0001$ \\
\hline
\end{tabular}

Table 8. Mean difference in log-transformed (Ln) heavy metal concentrations between 2011 and 2012 for blood samples of all adult Song Sparrows (Melospiza melodia) captured in the upper Santa Cruz River watershed, Arizona.

[Only significant heavy metals from a Student's t-test are reported along with standard error (SE), t-ratio t(205), and p-value (p). 2011, 94 Song Sparrows sampled; 2012, 113 Song Sparrows sampled]

\begin{tabular}{ccccc}
\hline Metal & Mean Dif. $[\mathbf{L n}(\mathbf{2 0 1 2})-\mathbf{L n}(\mathbf{2 0 1 1})]$ & $\mathbf{S E}$ & $\mathbf{t}(205)$ & $\mathbf{p}$ \\
\hline $\mathrm{Al}$ & -0.5172 & 0.12 & -4.37 & $<0.0001$ \\
$\mathrm{As}$ & -0.4864 & 0.15 & -3.24 & 0.0007 \\
$\mathrm{Cd}$ & -0.3404 & 0.07 & -4.66 & $<0.0001$ \\
$\mathrm{Cu}$ & -0.4609 & 0.06 & -7.23 & $<0.0001$ \\
$\mathrm{Fe}$ & -0.5112 & 0.05 & -10.26 & $<0.0001$ \\
$\mathrm{Hg}$ & -0.8075 & 0.11 & -7.32 & $<0.0001$ \\
$\mathrm{Mg}$ & -0.7321 & 0.05 & -14.29 & $<0.0001$ \\
$\mathrm{Mn}$ & -0.6785 & 0.10 & -6.50 & $<0.0001$ \\
$\mathrm{Mo}$ & -0.3318 & 0.07 & -4.61 & $<0.0001$ \\
$\mathrm{Ni}$ & 1.1338 & 0.19 & 5.93 & $<0.0001$ \\
$\mathrm{~Pb}$ & -0.5286 & 0.10 & -5.11 & $<0.0001$ \\
$\mathrm{Sr}$ & -0.4210 & 0.09 & -4.57 & $<0.0001$ \\
$\mathrm{Tl}$ & -0.4132 & 0.10 & -3.98 & $<0.0001$ \\
$\mathrm{~V}$ & -0.4372 & 0.13 & -3.49 & 0.0003 \\
$\mathrm{Zn}$ & -0.4827 & 0.07 & -7.26 & $<0.0001$ \\
\hline
\end{tabular}


This page left intentionally blank 